\title{
Impact of Metal and Metal Oxide Nanoparticles on Plant: A Critical Review
}

\author{
Anshu Rastogi 1, 2*, Marek Zivcak ${ }^{2}$, Oksana Sytar ${ }^{2,3}$, Hazem M. Kalaji, ${ }^{4,}$, Xiaolan $\mathrm{He}^{6}$, \\ Sonia Mbarki ${ }^{7}$ and Marian Brestic ${ }^{2 *}$
}

${ }^{1}$ Department of Meteorology, Poznan University of Life Sciences, Poznan, Poland, ${ }^{2}$ Department of Plant Physiology, Slovak University of Agriculture, Nitra, Slovakia, ${ }^{3}$ SRL "Physiological Bases of Plant Productivity," Educational and Scientific Center "Institute of Biology and Medicine," Taras Shevchenko National University of Kyiv, Kiev, Ukraine, ${ }^{4}$ SI Technology, Warsaw, Poland, ${ }^{5}$ Department of Plant Physiology, Faculty of Agriculture and Biology, Warsaw University of Life Science-SGGW, Warsaw, Poland, ${ }^{6}$ Jiangsu Academy of Agricultural Sciences, Nanjing, China, ${ }^{7}$ National Research Institute of Rural Engineering, Water and Forests, Aryanah, Tunisia

An increasing need of nanotechnology in various industries may cause a huge environment dispersion of nanoparticles in coming years. A concern about nanoparticles interaction with flora and fauna is raised due to a growing load of it in the environment. In recent years, several investigators have shown impact of nanoparticles on plant growth and their accumulation in food source. This review examines the research performed in the last decade to show how metal and metal oxide nanoparticles are influencing the plant metabolism. We addressed here, the impact of nanoparticle on plant in relation to its size, concentration, and exposure methodology. Based on the available reports, we proposed oxidative burst as a general mechanism through which the toxic effects of nanoparticles are spread in plants. This review summarizes the current understanding and the future possibilities of plant-nanoparticle research.

Keywords: nanoparticles, nanotoxicology, oxidative stress, industrial pollutants, silver nanoparticles (Ag-NPs)

\section{INTRODUCTION}

Nanoparticles are classified as a material in which at least one dimension is $<100 \mathrm{~nm}$ in diameter (Auffan et al., 2009). Nanoparticles are not new to the environment and occur naturally in the form of minerals, clays, and products of bacteria. It has been used since ancient times as a colorant for metals, but the systematic design and engineering of nanoparticles for various uses has started only in the last few decades (Maurer-Jones et al., 2013). Engineered nanoparticles are designed to have the properties which are not present in bulk samples of the same materials (Auffan et al., 2009). Engineered nanoparticles are composed of a variety of materials and occur in different sizes and shapes with a suite of synthetic surface molecules, which makes them distinct from naturally occurring materials (Radad et al., 2012; Maurer-Jones et al., 2013). Metal and metal oxides nanoparticles exhibit different physiochemical properties and are different than their native bulk compounds in several respects which includes its surface, optical, thermal, and electrical properties. Metal and metal oxide nanoparticles are manufactured by addition of reducing or oxidizing/precipitating agents during their synthesis, respectively (Sanchez-Dominguez et al., 2009). Several factors are responsible for nanoparticles reactivity with biomolecules which includes nanoparticles size, core composition, shape, surface properties, purity, stability, and method of manufacturing (Teske and Detweiler, 2015; Wang P. et al., 2016). There is a good chance that 
nanoparticles may retain the major characteristic of their bulk material, therefore, it is needed to consider the impact of bulk material while the study of nanoparticles interaction in environment, for example, heavy metals are toxic to plants whereas silicon as a metalloid was observed to be beneficial for plants (Yadav, 2010; Tubana et al., 2016; Helaly et al., 2017).

In the last decades, nanoparticles have been used in various household and industrial products. Due to the increasing use of nanoparticles in commercial products, different industries are developing novel nanoparticles for the improvement of their services and products. Some of the industries with an intensive use of nanoparticles, in which can be expected the release of nanoparticles to the environment, are indicated in Figure 1. A few of the many nanoparticles are used on a very large scale and have the potential for making its way into the environment. The nanoparticles can contaminate the environment through various processes such as, the improper management of industrial waste and improper disposal of products by the users. Several mathematical models are being developed to estimate the release of nanoparticles to the environment (Keller and Lazareva, 2014; Dumont et al., 2015). According to consumption of Silver nanoparticle (AgNP), and Zinc oxide nanoparticles in Europe per person, their release has been assumed to be significant and broadly distributed in European territory (Dumont et al., 2015). Keller and Lazareva (2014) have also estimated a significant release of different nanoparticles to the environment. In addition nanoparticles are susceptible to environmental conditions and can change their aggregation state, oxidation state, precipitation of secondary phases etc., in different environmental condition (Levard et al., 2012). The physical parameters and chemicals presence in different environment influence the stability of nanoparticles. Therefore, nanoparticles may behave differently in different condition (Levard et al., 2012), and thus their availability and reactivity in ecosystem is affected. The composition of nanoparticles may also change their properties and therefore their reactivity, penetration and translocation inside the plant which may leads to different responses of plants to the same nanoparticle, for example, Barrios et al. (2016) has shown that capping of nanoparticles influences the plant responses compared to exposure to bare nanoparticle. Plants are in continuous interaction with air, soil, and water, all of which may contain engineered nanoparticles. As the plants are also consumed by animals, the nanoparticles may be transferred to them. There is a risk that nanoparticles could invade the food chain and become dangerous to humans (the last link in the food chain). This is especially important, as the excessive usage of nanoparticles and their abundance in the environment would increase and, as a result, both plants and animals may become the source of nanoparticles for humans. Few studies in recent year confirm the trophic transfer of different nanoparticles through a terrestrial or aquatic food chain (Judy et al., 2012; Unrine et al., 2012; Hawthorne et al., 2014; De la Torre Roche et al., 2015; Tangaa et al., 2016).

Despite the plants are producers and play a major role in the ecosystem, the impact of nanoparticles upon them is not well studied (Rico et al., 2011; Feng et al., 2013; ZuverzaMena et al., 2017). The lack of proper detection methods for nanoparticles from environments makes the study of the nanoparticles complicated (Navratilova et al., 2015; Mahdi et al., 2017). Among different possible techniques, inductively coupled plasma mass spectroscopy (ICP-MS) is one of the most reliable techniques for the detection of nanoparticles (Hadioui et al., 2015; Navratilova et al., 2015; Mahdi et al., 2017). The research performed on different plants has shown that the nanoparticles may have both a positive and a negative impact on plants, depending on size, concentration, chemical composition, zeta potential, stability, and the shape of nanoparticles (Mirzajani

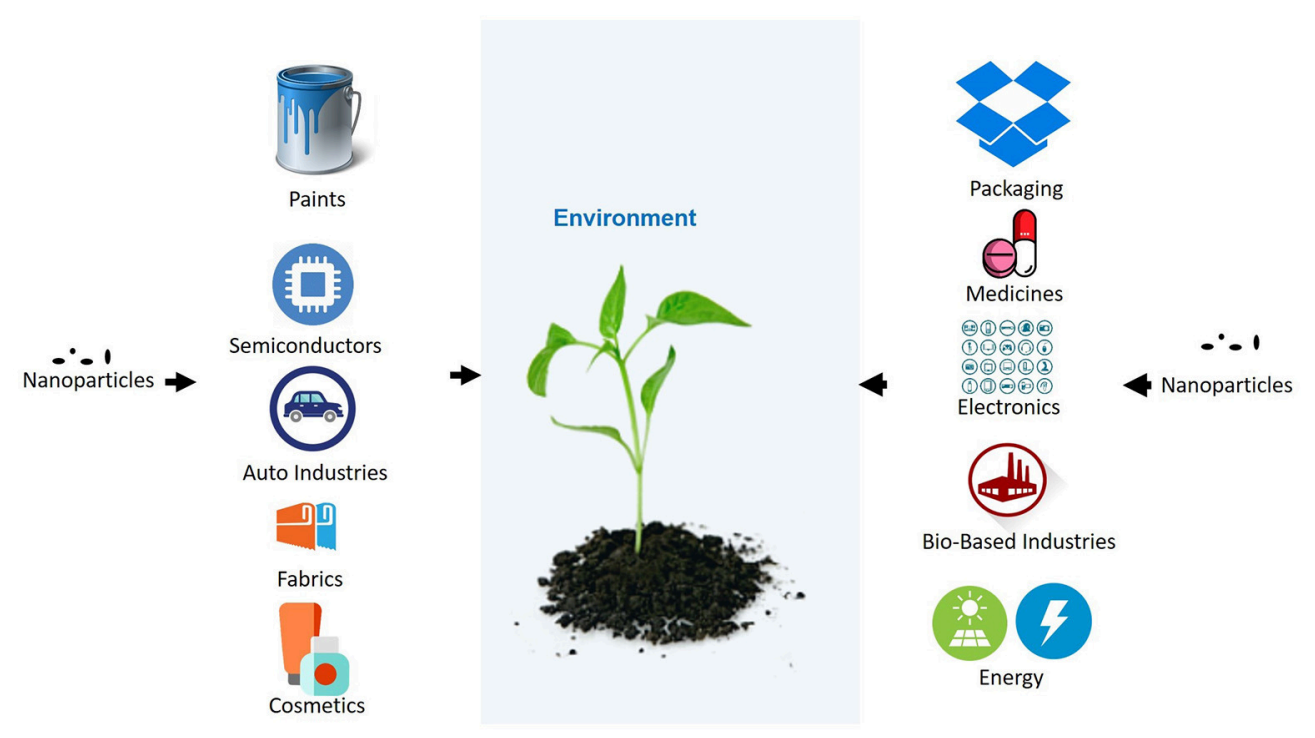

FIGURE 1 | Uses of nanoparticles in different industries and its leakage to environment. 
et al., 2013; Rafique et al., 2014; Nhan et al., 2015; Tripathi et al., 2015, 2017; Costa and Sharma, 2016; Wang Z. et al., 2016). Several studies have depicted a negative impact of nanoparticles on plants in the form of decrease in plant growth, productivity and pigments (Landa et al., 2016; Tripathi et al., 2017). On the other hand, smartly designed nanoparticles are also used for the betterment of agricultural crop production, as growth stimulators, nanopesticides, nanofertilizers, soil improving agents, or sensors for monitoring different agricultural parameters in the field (Fraceto et al., 2016; Wang P. et al., 2016). Due to the increased interest in the area, most of the research depicting the influence of industrial nanoparticles on plants has been performed in recent years. Therefore, the purpose of this review is to systematically present and analyze the research performed in the last 10 years to give an overview of the recent advancement in the field.

In the following sections, we will discuss the presence of different types of nanoparticles in the environment, the impact of different nanoparticles on plants, and a concise discussion and a general mechanism through which nanoparticles may cause an impact on the plant.

\section{EFFECT OF NANOPARTICLES ON PLANTS}

Nanoparticles cover a heterogeneous range of materials (Santos et al., 2015), but only a few of them are extensively used and at present, the environment is at risk to be exposed to them. Metal and metal oxide nanoparticles of titanium dioxide $\left(\mathrm{TiO}_{2}\right)$, silver, zinc oxide, cerium dioxide, copper, copper oxide, aluminum, nickel, and iron are most commonly used in industries and therefore are mostly studied for their impacts on different plants. Some non-metal nanoparticles, such as, single-walled carbon nanotubes and fullerene have been well studied to reveal their nanotoxicity mechanisms (Joner et al., 2008). From another side, enhancing growth together with an acceleration of seed germination for different organs of corn, tomato, rice, and soybean has been observed under exposure to single-walled carbon nanohorns (SWCNHs) (Lahiani et al., 2015). In recent years, nanoparticles have been developed to be used in agriculture as nanopesticides and nanofertilizers (which include the use of nanoparticles as nanocarrier for pesticides, fertilizers; Fraceto et al., 2016; Wang P. et al., 2016). Nanoparticles of chitosan were used to encapsulated herbicide, due to which the efficiency of herbicide was observed to be enhanced significantly (Maruyama et al., 2016). Mesoporous silicon nanoparticles as a metalloid nanoparticles have also been used to deliver DNA, proteins, and other chemicals in plants (Torney et al., 2007; MartinOrtigosa et al., 2014). Use in agriculture includes nanoparticles, such as, nanozeolites (basic building blocks of silicate $\left[\mathrm{SiO}_{4}\right]^{-}$ and aluminates $\left[\mathrm{AlO}_{4}\right]^{-}$tetrahedrons) as well as the hydrogels (consisting of different polymers such as, chitosan and alginate), which helps in the improvement of soil quality, and nanosensors (for monitoring plant and soil health; Fraceto et al., 2016). Silica nanoparticles were observed to be nontoxic to plant (Slomberg and Schoenfisch, 2012), but some authors observed the toxic effect due to decrees in $\mathrm{pH}$ of the media after addition of nanoparticles. Tripathi et al. (2015) have studied that Silica nanoparticle was able to alleviate chromium (VI) phytotoxicity in Pisum sativum (L.) seedlings (Tripathi et al., 2015). Several studies on the impact of metal and metal oxide nanoparticles on plant have shown a toxic impact on plants, whereas few studies also indicated their beneficial role in the form of enhancing plant growth parameters and productivity (Castiglione et al., 2011; Clément et al., 2013; Dimkpa et al., 2013; Jaberzadeh et al., 2013; Jiang et al., 2014; Rafique et al., 2014; Raliya et al., 2015; Okupnik and Pflugmacher, 2016; Cvjetko et al., 2017; Tripathi et al., 2017).

To determine whether the metal and metal oxide nanoparticles represent a risk to plant organisms and the environment, analytical selection of information is needed regarding size, concentration, zeta potential, uptake by a certain type of plants and effects on the plant. In particular, the zeta potential represents an important reliable indicator of nanoparticle coagulation and reactivity in solution. Zeta potential indicates total electric potential of all particles and ions in solution, and thus get effected by changes in $\mathrm{pH}$ or ionic strength (Teske and Detweiler, 2015). The effect of nanoparticles on plants occurs in several physiological, morphological, and genotoxic changes. Therefore, for the effective use of nanotechnology in agriculture, it is important to know the role of certain nanoparticle (Nair, 2016). Effect of different metal and metal oxide nanoparticles on different plants is observed to be variable and ranges from their positive impact to the lethal impact in plants (Tables 1-4). To clearly compare the different studies, it is divided into four following sections.

\section{Impact of Silver Nanoparticles (AgNP)}

Among different nanoparticles, AgNPs are fetching more attention because of their intensive uses in various products, which includes their uses as antimicrobial agents, shampoo, soap, toothpaste, waste water treatment, food packaging materials, food storage containers, fabrics, room sprays, detergents, paint, etc. (Boxall et al., 2008; Rai et al., 2009; Wijnhoven et al., 2009). Due to its extensive use, the production of nanoparticles is increasing rapidly, among which the United States itself has been reported to produce 2,500 tons/year of AgNP, of which around 150 tons end up in sewage sludge and 80 tons in surface waters (Khaydarov et al., 2009; El-Temsah and Joner, 2012). Through sludge and surface water the AgNP may easily reach to the plants.

The AgNPs of $25 \mathrm{~nm}$ at high concentration was observed to break the cell wall and damage the vacuoles of root cells of Oryza sativa, thus causing a toxic effect (Mazumdar and Ahmed, 2011). Mirzajani et al. (2013) observed that the AgNP was unable to penetrate the root cells of $O$. sativa when present in low concentration (up to $30 \mu \mathrm{g} / \mathrm{mL}$ ), whereas the higher concentration was able to destroy the cell structure and cause the toxic effect. The authors also reported that, the $30 \mu \mathrm{g} / \mathrm{mL}$ accelerates root growth, whereas $60 \mu \mathrm{g} / \mathrm{mL}$ restrict the ability of root to grow. The observations indicate that the penetration of AgNP is necessary to cause a toxic effect, whereas when present in surrounding, it may have a positive impact on plants. Krishnaraj et al. (2012) observed a mild or no effect of biologically synthesized AgNP on Bacopa 
TABLE 1 | Impact of AgNP on plants.

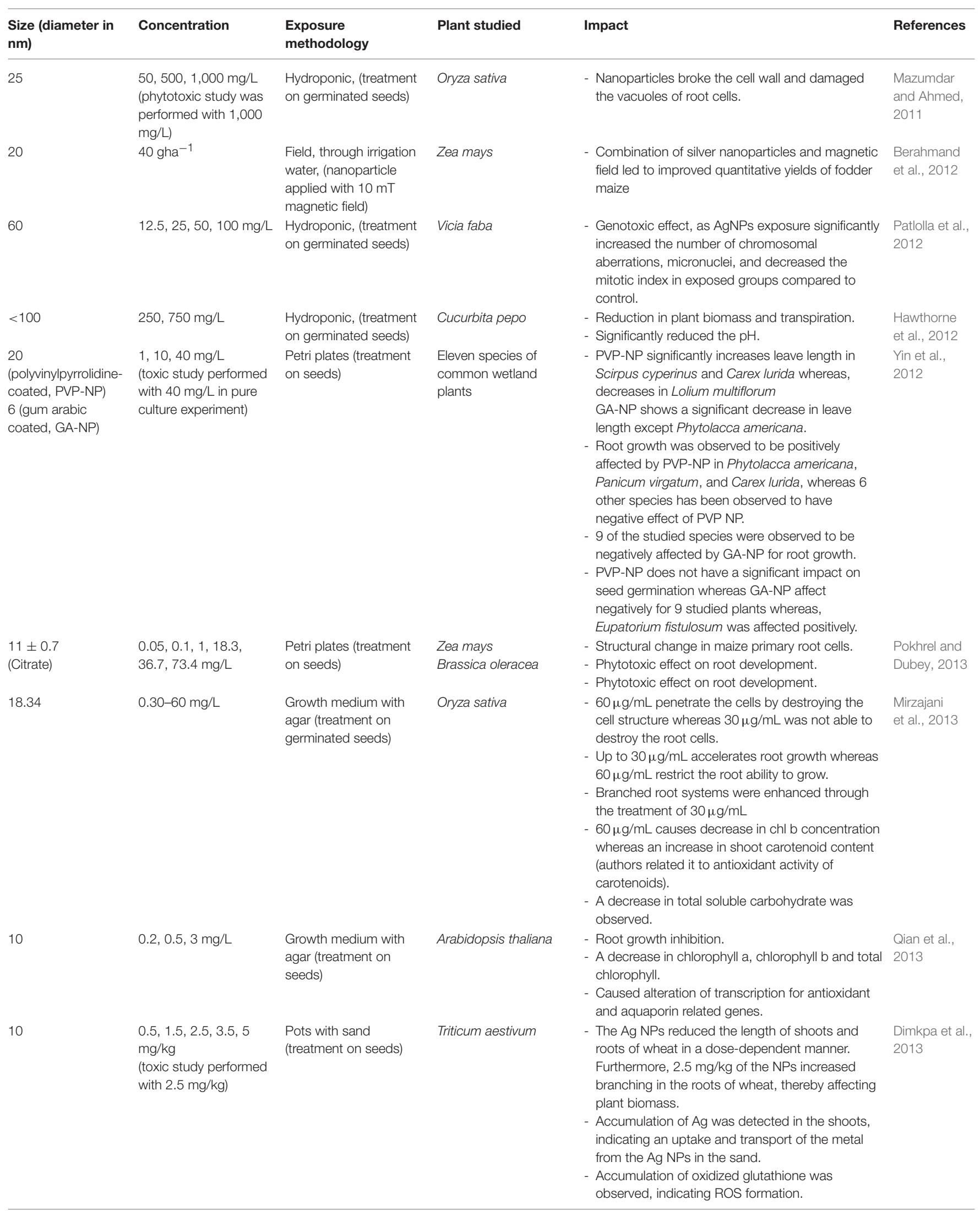


TABLE 1 | Continued

\begin{tabular}{|c|c|c|c|c|c|}
\hline $\begin{array}{l}\text { Size (diameter in } \\
\mathrm{nm} \text { ) }\end{array}$ & Concentration & $\begin{array}{l}\text { Exposure } \\
\text { methodology }\end{array}$ & Plant studied & Impact & References \\
\hline 6 and 20 & $0.5,5,10 \mathrm{mg} / \mathrm{L}$ & $\begin{array}{l}\text { Hydroponic (treatment } \\
\text { on grown plant) }\end{array}$ & Spirodela polyrhiza & $\begin{array}{l}\text { - Dose dependent increase in levels of ROS, } \\
\text { superoxide dismutase, peroxidase, and } \\
\text { glutathione activity. }\end{array}$ & $\begin{array}{l}\text { Jiang et al., } \\
2014\end{array}$ \\
\hline 200-800 & $1 \mathrm{mg} / \mathrm{L}$ & $\begin{array}{l}\text { Growth medium with } \\
\text { Agar }+ \text { pots with soil } \\
\text { (treatment on } \\
\text { germinated seeds) }\end{array}$ & $\begin{array}{l}\text { Trigonella } \\
\text { foenum-graecum }\end{array}$ & $\begin{array}{l}\text { - Enhancement in plant growth and diosgenin } \\
\text { synthesis was observed. }\end{array}$ & $\begin{array}{l}\text { Jasim et al., } \\
2016\end{array}$ \\
\hline $35-40$ & $50,75 \mathrm{mg} / \mathrm{L}$ & $\begin{array}{l}\text { Pots (foliar treatment on } \\
\text { grown plant) }\end{array}$ & $\begin{array}{l}\text { Triticum aestivum, } \\
\text { Vigna sinensis } \\
\text { Brassica juncea }\end{array}$ & $\begin{array}{l}\text { - Relatively unaffected (wheat) } \\
\text { - The optimum growth promotion and increased } \\
\text { root nodulation were observed at } 50 \text { ppm } \\
\text { treatment (cowpea). } \\
\text { - Improved shoot parameters were recorded at } 75 \\
\text { ppm (brassica). }\end{array}$ & $\begin{array}{l}\text { Pallavi et al., } \\
2016\end{array}$ \\
\hline 2 & $0,125,250,500 \mathrm{mg} / \mathrm{L}$ & $\begin{array}{l}\text { Petri plates (treatment } \\
\text { on seeds) }\end{array}$ & Raphanus sativus & $\begin{array}{l}\text { - Seed germination was not affected. } \\
\text { - A concentration-dependent reduction in seedling } \\
\text { elongation and water content was observed. } \\
\text { - The seedlings exposed to } 500 \mathrm{mg} / \mathrm{L} \text { was } \\
\text { observed to have significantly less } \mathrm{Ca}, \mathrm{Mg}, \mathrm{B}, \mathrm{Cu} \text {, } \\
\text { Mn, and Zn, compared with the control. } \\
\text { - The infrared spectroscopy analysis showed } \\
\text { changes in the bands corresponding to lipids } \\
\left.\left.\text { (3000-2800 } \mathrm{cm}^{-1}\right) \text {, proteins (1550-1530 } \mathrm{cm}^{-1}\right) \text {, } \\
\text { and structural components of plant cells such as, } \\
\text { lignin, pectin, and cellulose }\end{array}$ & $\begin{array}{l}\text { Zuverza- } \\
\text { Mena et al., } \\
2016\end{array}$ \\
\hline 20 & $5,10,20 \mathrm{mg} / \mathrm{L}$ & $\begin{array}{l}\text { Hydroponic (treatment } \\
\text { on bulb with } 2-3 \mathrm{~cm} \\
\text { roots) }\end{array}$ & Allium cepa & $\begin{array}{l}\text { Various chromosomal aberrations were induced in } \\
\text { both mitotic and meiotic cells even at lower } \\
\text { concentrations of bio-AgNPs. }\end{array}$ & $\begin{array}{l}\text { Saha and } \\
\text { Dutta Gupta, } \\
2017\end{array}$ \\
\hline $\begin{array}{l}61.2 \pm 33.9 \text { (Citrate) } \\
9.4 \pm 1.3(\mathrm{PVP}) \\
5.6 \pm 2.1 \text { (CTAB) }\end{array}$ & $25,50,75,100 \mu \mathrm{M}$ & $\begin{array}{l}\text { Hydroponic (treatment } \\
\text { on bulb with } 2-3 \mathrm{~cm} \\
\text { roots) }\end{array}$ & Allium сера & $\begin{array}{l}\text { - Highest concentration of CTAB coted NP was } \\
\text { observed in root, responsible for relatively higher } \\
\text { inhibition in root growth, increase in ROS and } \\
\text { antioxidant and DNA lysis. }\end{array}$ & $\begin{array}{l}\text { Cvjetko et al., } \\
2017\end{array}$ \\
\hline 20 & $1000,3000 \mu \mathrm{M}$ & $\begin{array}{l}\text { Petri plates and } \\
\text { hydroponic (treatment } \\
\text { on seeds) }\end{array}$ & Pisum sativum & $\begin{array}{l}\text { - Significantly stimulated the activities of superoxide } \\
\text { dismutase (SOD) and ascorbate peroxidase (APX) } \\
\text { while inhibited activities of glutathione reductase } \\
\text { (GR) and dehydroascorbate reductase (DHAR). } \\
\text { - Declined growth parameters, photosynthetic } \\
\text { pigments and chlorophyll fluorescence. } \\
\text { - Nitric oxide alleviated the impact of AgNP by } \\
\text { regulating Ag uptake, antioxidant system, } \\
\text { oxidative stress and anatomical structures of root } \\
\text { and shoot }\end{array}$ & $\begin{array}{l}\text { Tripathi et al., } \\
2017\end{array}$ \\
\hline $\begin{array}{l}12.9 \pm 9.1(90 \%) \\
\text { nanoparticles in } \\
\text { ultrapure water }\end{array}$ & $\begin{array}{l}0.01,0.05,0.1,0.5,1 \\
\mathrm{mg} / \mathrm{L}\end{array}$ & $\begin{array}{l}\text { Pots with soil (treatment } \\
\text { on seedling) }\end{array}$ & Capsicum annuum & $\begin{array}{l}\text { - Concentration dependent decrease in plant } \\
\text { growth. } \\
\text { - Concentration dependent increase in cytokinin } \\
\text { concentration }\end{array}$ & $\begin{array}{l}\text { Vinković } \\
\text { et al., } 2017\end{array}$ \\
\hline$<100$ & $1.5 \mathrm{mg} / \mathrm{L}$ & $\begin{array}{l}\text { Hydroponic and pots } \\
\text { (treatment on seeds) }\end{array}$ & $\begin{array}{l}\text { Triticum aestivum } \\
\text { (Wheat- } \\
\text { Pseudocercosporella } \\
\text { herpotrichoides } \\
\text { Phytosystem) }\end{array}$ & $\begin{array}{l}\text { - In Myronivska } 808 \text { the lipid peroxidation was } \\
\text { observed to be significantly high where } \\
\text { nanoparticle was present with pathogen. }\end{array}$ & $\begin{array}{l}\text { Belava et al., } \\
2017\end{array}$ \\
\hline
\end{tabular}

monnieri. The synthesized nanoparticle induced the protein and carbohydrate synthesis and decreased the total phenol contents, which can be considered as a positive effect, it may be due to the presence of different size $(2-50 \mathrm{~nm})$ of nanoparticle with different penetration capacity in the highest applied concentration $(100 \mathrm{ppm})$, or the different chemical property of biologically synthesized NP. The AgNP of $200-800 \mathrm{~nm}$ size was observed to enhance the plant growth (Jasim et al., 2016), whereas $35-40 \mathrm{~nm}$ of AgNP was observed to positively influence the root and shoot growth of different plant (Pallavi et al., 2016), which may be due to the inability of the penetration of large nanoparticles in studied low concentration as reported by Mirzajani et al. (2013). Different size of AgNP used in the various studies shows a clear correlation between the size and 
TABLE 2 | Impact of $\mathrm{Cu}$ and $\mathrm{CUO}$ NP on plants.

\begin{tabular}{|c|c|c|c|c|c|}
\hline $\begin{array}{l}\text { Size (diameter in } \\
\mathrm{nm} \text { ) }\end{array}$ & Concentration & $\begin{array}{l}\text { Exposure } \\
\text { methodology }\end{array}$ & Plant studied & Impact & References \\
\hline $\begin{array}{l}\text { Around } 20(\mathrm{Cu} \\
\text { nanoparticle) }\end{array}$ & $\begin{array}{l}200,400,600,800 \\
1,000 \mathrm{mg} / \mathrm{L}\end{array}$ & $\begin{array}{l}\text { Growth medium with } \\
\text { Agar (treatment on } \\
\text { germinated seeds) }\end{array}$ & $\begin{array}{l}\text { Phaseolus radiates } \\
\text { Triticum aestivum }\end{array}$ & $\begin{array}{l}\text { - Decrease in seedling and shoot growth with an } \\
\text { increase in nanoparticle concentration. } \\
\text { - In P. radiates no adverse effect on shoot growth } \\
\text { was observed till } 800 \mathrm{mg} / L \text { concentration whereas } \\
\text { in T. aestivum shoot growth was effected even at } \\
200 \mathrm{mg} / \mathrm{L} \text { concentration. } \\
\text { - Roots were more effected by the nanoparticles } \\
\text { than the shoot. }\end{array}$ & $\begin{array}{l}\text { Lee et al., } \\
2008\end{array}$ \\
\hline 30 (CuO) & $\begin{array}{l}0.025,0.25,0.5,1,5 \\
\mathrm{mg} / \mathrm{L}\end{array}$ & $\begin{array}{l}\text { Hydroponic (treatment } \\
\text { on plants) }\end{array}$ & Elodea densa & $\begin{array}{l}\text { - Catalase and superoxide dismutase activities } \\
\text { increases by } 1.5 \text { to } 2 \text { times. } \\
\text { - stimulated photosynthesis upto } 0.25 \mathrm{mg} / \mathrm{L} \text { level } \\
\text { whereas suppress it above } 1 \mathrm{mg} / \mathrm{L} \text { concentration. }\end{array}$ & $\begin{array}{l}\text { Nekrasova } \\
\text { et al., } 2011\end{array}$ \\
\hline <100 (CuO) & $\begin{array}{l}10,100,50,1,000 \\
\mathrm{mg} / \mathrm{L}\end{array}$ & $\begin{array}{l}\text { Petri plates (treatment } \\
\text { on seeds) }\end{array}$ & $\begin{array}{l}\text { Raphanus sativus } \\
\text { Lolium perenne } \\
\text { Lolium rigidum }\end{array}$ & $\begin{array}{l}\text { - The DNA damaged was found to be increased } \\
\text { (DNA lesions compound) with an increase in } \\
\text { concentration of nanoparticles. }\end{array}$ & $\begin{array}{l}\text { Atha et al., } \\
2012\end{array}$ \\
\hline $\begin{array}{l}30-40 \\
-(\mathrm{CuO})\end{array}$ & $\begin{array}{l}680 \pm 60,1,004 \pm \\
120,2,008 \pm 340 \\
4,051 \pm 950 \mathrm{mg} / \mathrm{L}\end{array}$ & $\begin{array}{l}\text { Hydroponic (treatment } \\
\text { on seeds) }\end{array}$ & Lemna gibba & $\begin{array}{l}\text { - Dose-dependent decrease in plant growth, and } \\
\text { PS II activity. } \\
\text { - Inactivation of PSII reaction centers, a decrease in } \\
\text { electron transport, and an increase in thermal } \\
\text { energy dissipation. }\end{array}$ & $\begin{array}{l}\text { Perreault } \\
\text { et al., } 2014\end{array}$ \\
\hline$<50$ (CuO) & $0.5,1,1.5 \mathrm{mM}$ & $\begin{array}{l}\text { Cotton pads shocked } \\
\text { with growth media } \\
\text { (treatment on seeds) }\end{array}$ & Barley & $\begin{array}{l}\text { - Dose dependent reduction in shoot and root } \\
\text { growth } \\
\text { - Significant decrease in GSH/GSSG ratio } \\
\text { - Increase in hydrogen peroxide and lipid } \\
\text { peroxidation with increased concentration of NP. }\end{array}$ & $\begin{array}{l}\text { Shaw et al., } \\
2014\end{array}$ \\
\hline $43 \pm 9$ (CuO) & $\begin{array}{l}100,200,500,1,000 \\
\mathrm{mg} / \mathrm{L}\end{array}$ & $\begin{array}{l}\text { Petri plates or } \\
\text { hydroponic (treatment } \\
\text { on seeds or germinated } \\
\text { seeds) }\end{array}$ & Elsholtzia splendens & $\begin{array}{l}\text { - Dose-dependent decrease in root length. } \\
\text { - NPs were absorbed by roots and translocated to } \\
\text { shoots. } \\
\text { - Dose-dependent decrease in chlorophyll a, b and } \\
\text { total chlorophyll was observed. }\end{array}$ & $\begin{array}{l}\text { Shi et al., } \\
2014\end{array}$ \\
\hline 30-50 (CuO) & 10 mg/L & $\begin{array}{l}\text { Hydroponic (treatment } \\
\text { on plant) }\end{array}$ & Elodea nuttallii & $\begin{array}{l}\text { - Ultraviolet (UV) radiation treatment increases the } \\
\text { Cu concentration in shoot. } \\
\text { - UV radiation enhances the phytotoxic effect of } \\
\text { nanoparticle. }\end{array}$ & $\begin{array}{l}\text { Regier et al., } \\
2015\end{array}$ \\
\hline$<50(\mathrm{CuO})$ & $\begin{array}{l}2.5,10,50,100,1,000 \\
\mathrm{mg} / \mathrm{L}\end{array}$ & $\begin{array}{l}\text { Petri plate and } \\
\text { hydroponic (treatment } \\
\text { on seeds) }\end{array}$ & Oryza sativa & $\begin{array}{l}\text { - Accumulation of nanoparticles in chloroplast. } \\
\text { - Dose-dependent decrease in thylakoid number } \\
\text { per grana, Photosynthetic rate, transpiration rate, } \\
\text { stomatal conductance, maximal quantum yield of } \\
\text { PSIl photochemistry, and photosynthetic pigment } \\
\text { contents. } \\
\text { - Dose-dependent increase in ascorbate } \\
\text { peroxidase and superoxide dismutase. }\end{array}$ & $\begin{array}{l}\text { Costa and } \\
\text { Sharma, } \\
2016\end{array}$ \\
\hline 40 (CuO) & $\begin{array}{l}\text { 10, 50, 100, 150, } 200 \\
\mathrm{mg} / \mathrm{L}\end{array}$ & $\begin{array}{l}\text { Hydroponic (treatment } \\
\text { on plants) }\end{array}$ & Lemna minor & $\begin{array}{l}\text { - Increase in peroxidase, catalase, superoxide } \\
\text { dismutase activity. } \\
\text { - Increase in lipid peroxidation. } \\
\text { - Inhibition of plant growth. }\end{array}$ & $\begin{array}{l}\text { Song et al., } \\
2016\end{array}$ \\
\hline
\end{tabular}


TABLE 2 | Continued

\begin{tabular}{|c|c|c|c|c|c|}
\hline $\begin{array}{l}\text { Size (diameter in } \\
\text { nm) }\end{array}$ & Concentration & $\begin{array}{l}\text { Exposure } \\
\text { methodology }\end{array}$ & Plant studied & Impact & References \\
\hline$<50(\mathrm{CuO})$ & $3,10,30,300 \mathrm{mg} / \mathrm{Kg}$ & $\begin{array}{l}\text { Pots with sand } \\
\text { (treatment on seeds) }\end{array}$ & Wheat & $\begin{array}{l}\text { - Inhibition of root elongation by CuO NP (>10 } \\
\text { mg/kg). } \\
\text { - exposure resulted in root hair proliferation and } \\
\text { shortening of the zones of division and elongation. }\end{array}$ & $\begin{array}{l}\text { Adams et al., } \\
2017\end{array}$ \\
\hline $\begin{array}{l}30 \pm 10 \\
(\mathrm{CuO})\end{array}$ & $10,200,1,000 \mathrm{mg} / \mathrm{L}$ & $\begin{array}{l}\text { Hydroponic (treatment } \\
\text { on plants) }\end{array}$ & $\begin{array}{l}\text { Transgenic cotton } \\
\text { (Bt-29317) } \\
\text { Conventional cotton } \\
\text { (Jihe321) }\end{array}$ & $\begin{array}{l}\text { - Decrease in growth, development, nutrient } \\
\text { content, indole-3-acetic acid (IAA) and abscisic } \\
\text { acid (ABA) concentrations. } \\
\text { - reduce the uptake of nutrients, such as, B, Mo, } \\
\mathrm{Mn}, \mathrm{Mg}, \mathrm{Zn} \text { and } \mathrm{Fe} \text {, and inhibit the transport of } \mathrm{Na} \\
\text { and } \mathrm{Mn} \text { in cotton plants. } \\
\text { - Enhance the expression of Bt- toxin protein in } \\
\text { leaves and roots. }\end{array}$ & $\begin{array}{l}\text { Van et al., } \\
2016\end{array}$ \\
\hline $\begin{array}{l}20-40 \\
(\mathrm{CuO})\end{array}$ & $20,50 \mathrm{mg} / \mathrm{L}$ & $\begin{array}{l}\text { Hydroponic (treatment } \\
\text { on seeds) }\end{array}$ & Arabidopsis thaliana & $\begin{array}{l}\text { - Inhibit seedling growth of different ecotypes } \\
\text { (Col-0, Bay-0, and Ws-2). } \\
\text { - Col-0 was most sensitive ecotype to nanoparticle } \\
\text { among three. } \\
\text { - CuO NP was observed from root till seeds. }\end{array}$ & $\begin{array}{l}\text { Wang Z. } \\
\text { et al., } 2016\end{array}$ \\
\hline
\end{tabular}

toxic relation of NP to the plant, the NP with lower size was always observed to have higher toxicity to the plant compared to larger NP (Yin et al., 2012; Jiang et al., 2014; Cvjetko et al., 2017).

AgNPs (of comparatively small size i.e., $<30 \mathrm{~nm}$ ) when applied in high concentration were observed to inhibit the root and shoot growth in different plant studied (Dimkpa et al., 2013; Qian et al., 2013; Tripathi et al., 2017; Vinković et al., 2017). As a response to AgNP stress an enhancement in reactive oxygen species (ROS) was observed, which also leads to the enhanced production of antioxidant enzymes and molecules as an adaptive mechanism (Dimkpa et al., 2013; Jiang et al., 2014; Cvjetko et al., 2017; Tripathi et al., 2017). The AgNPs were also observed to cause an impact on DNA and influences the gene expression in several plants (Patlolla et al., 2012; Qian et al., 2013; Cvjetko et al., 2017; Saha and Dutta Gupta, 2017). Physiological impacts of AgNP was observed in the form of a decrease in transpiration (Hawthorne et al., 2012), chlorophyll concentration (Mirzajani et al., 2013; Qian et al., 2013; Tripathi et al., 2017); and chlorophyll fluorescence (Tripathi et al., 2017). A significant alteration in different macromolecules, lipids, proteins, lignin, pectin and cellulose were observed in Raphanus sativus when treated with $2 \mathrm{~nm}$ AgNP with $500 \mathrm{mg} / \mathrm{L}$ concentration (ZuverzaMena et al., 2016). Plant hormones such as, cytokinin and auxin were also observed to be affected by the AgNP (Yin et al., 2012; Vinković et al., 2017).

Recent studies have shown that when AgNP was combined with different treatment/compounds, it may have a different impact on plants (Berahmand et al., 2012; Belava et al., 2017; Tripathi et al., 2017). This can be explained by the influence of other phenomena/compound on AgNP. AgNP treatment in combination with magnetic field was observed to improve quantitative yields in Zea mays (Berahmand et al., 2012), whereas the nitric oxide was observed to alleviate the impact of AgNP by regulating Ag uptake, an antioxidant system, oxidative stress, and anatomical structure (Tripathi et al., 2017). In the wheat-pathogen phytosystem, an enhancement of lipid peroxidation was observed, when compared with NP or pathogen alone (Belava et al., 2017). Due to its fungicidal activity, AgNP have been tested against few plant-pathogenic fungi, and their impact was found to be significant in eliminating the fungi (Jo et al., 2009). But their use in agriculture is still questionable as $\mathrm{AgNP}$ is known to release silver ions with its age, moreover, they can affect the biomass accumulation in soil (Johansson et al., 1998; Liu and Hurt, 2010).

The study clearly indicates AgNP exhibit an impact on different aspect of plant morphology, physiology, and biochemistry, which depends on the size, properties, and concentration of the NP in use. On the basis of the indicated studies, it can be hypothesized that for exhibiting a toxic effects AgNP need to penetrate the plant tissue and interfere with different metabolic activities. For better understanding, the influence of different AgNP on a plant is summarized in Table $\mathbf{1 .}$

\section{Impact of Copper and Copper Oxide Nanoparticles}

Copper is an essential micronutrient, which is incorporated in many proteins and enzymes, therefore, playing a significant role in plant health and nutrition. Copper nanoparticles $(\mathrm{Cu}$ NP) are widely used in different commercial applications such as, an antimicrobial agent, catalysts, gas sensors, electronics, batteries, heat transfer fluids, etc. (Kasana et al., 2017). Due to its oxidative property, copper oxide nanoparticles (CuO NP) are assumed to have a higher toxic effect than $\mathrm{Cu}$ NP. CuO NP was observed to have a positive impact on Elodea densa (waterweed) and stimulate photosynthesis at low concentration $(<0.25 \mathrm{mg} / \mathrm{L})$, but the impact scenario completely changes with higher doses and at $1 \mathrm{mg} / \mathrm{L}$ concentration a clear suppression in photosynthesis was observed (Nekrasova et al., 2011). The root morphology was reported to be adversely affected with $\mathrm{Cu}$ and $\mathrm{CuO}$ NP, with almost complete inhibition with a high dose of NP (Lee et al., 2008; Adhikari et al., 2012; Perreault et al., 2014; Shaw et al., 2014; Song et al., 2016; Adams et al., 2017). CuO 
TABLE 3 | Impact of $\mathrm{TiO}_{2} \mathrm{NP}$ on plants.

\begin{tabular}{|c|c|c|c|c|c|}
\hline $\begin{array}{l}\text { Size (diameter in } \\
\mathrm{nm} \text { ) }\end{array}$ & Concentration & $\begin{array}{l}\text { Exposure } \\
\text { methodology }\end{array}$ & Plant studied & Impact & References \\
\hline 5 & 300 mg/L & $\begin{array}{l}\text { Pots (treatment on } \\
\text { seeds and leaves) }\end{array}$ & Spinacia oleraces & $\begin{array}{l}\text { - More than } 60 \% \text { increase in plant fresh and dry } \\
\text { weight. } \\
\text { - The amount of Rubisco activase increased by } \\
42 \% \text {, whereas, its activity increased } 2.5 \text { times, } \\
\text { compared to untreated samples. }\end{array}$ & $\begin{array}{l}\text { Gao et al., } \\
2008\end{array}$ \\
\hline 25 & 300 mg/L & $\begin{array}{l}\text { Hydroponic (treatment } \\
\text { on germinated seeds) }\end{array}$ & Zea mays & $\begin{array}{l}\text { - Leaf growth inhibition and transpiration via } \\
\text { physical effects on root water transport }\end{array}$ & $\begin{array}{l}\text { Asli and } \\
\text { Neumann, } \\
2009\end{array}$ \\
\hline$<100$ & $\begin{array}{l}2,000,10,000,20,000 \\
40,000 \mathrm{mg} / \mathrm{L}\end{array}$ & $\begin{array}{l}\text { Petri plate (treatment on } \\
\text { seeds) }\end{array}$ & $\begin{array}{l}\text { Vicia narbonensis } \\
\text { Zea mays }\end{array}$ & $\begin{array}{l}\text { - Decrease in root elongation. } \\
\text { - Decrease in mitotic index. } \\
\text { - Increase in aberration index. }\end{array}$ & $\begin{array}{l}\text { Castiglione } \\
\text { et al., } 2011\end{array}$ \\
\hline $\begin{array}{l}14 \\
25 \\
140\end{array}$ & 100 mg/L & $\begin{array}{l}\text { Hydroponic (treatment } \\
\text { on plant) }\end{array}$ & $\begin{array}{l}\text { Brassica napus } \\
\text { Triticum aestivum }\end{array}$ & $\begin{array}{l}\text { - Absorbed by plants, with Brassica having higher } \\
\text { capacity to absorbed nanoparticle. ( } 14 \mathrm{~nm} \text { particle } \\
\text { was absorbed more than } 25 \mathrm{~nm}) \\
\text { - Moderate or no effect on plant growth. } \\
\text { - Accumulation in roots } \mathrm{TiO}_{2}-\mathrm{NPs} \text { with a primary } \\
\text { diameter lower than } 140 \mathrm{~nm}\end{array}$ & $\begin{array}{l}\text { Larue et al., } \\
2012\end{array}$ \\
\hline No description & $100,200,300$ mg/L & Field (treatment on plant) & Triticum aestivum & $\begin{array}{l}\text { - Titanium dioxide nanoparticles at } 0.02 \% \\
\text { increased different agronomic traits including } \\
\text { gluten and starch content under water deficit } \\
\text { condition. }\end{array}$ & $\begin{array}{l}\text { Jaberzadeh } \\
\text { et al., } 2013\end{array}$ \\
\hline 15 & 100 mg/L & $\begin{array}{l}\text { Petri plates (treatment } \\
\text { on seeds) }\end{array}$ & Linum usitatissimum & $\begin{array}{l}\text { - Reduction in root biomass, and root length. } \\
\text { - Reduction in seed germination after } 24 \mathrm{~h} \text {. }\end{array}$ & $\begin{array}{l}\text { Clément } \\
\text { et al., } 2013\end{array}$ \\
\hline 21 & $10,100,1,000 \mathrm{mg} / \mathrm{L}$ & $\begin{array}{l}\text { Hydroponic (treatment } \\
\text { on bulb with } 2-3 \mathrm{~cm} \\
\text { roots) }\end{array}$ & Allium cepa & - Concentration dependent increase in genotoxicity. & $\begin{array}{l}\text { Demir et al., } \\
2014\end{array}$ \\
\hline 90-98 & $12.5,25,50,100 \mathrm{mg} / \mathrm{L}$ & $\begin{array}{l}\text { Hydroponic, (treatment } \\
\text { on bulb with } 2-3 \mathrm{~cm} \\
\text { roots) }\end{array}$ & Allium cepa & $\begin{array}{l}\text { - Concentration dependent increase in ROS. } \\
\text { - Concentration dependent increase in genotoxicity. }\end{array}$ & $\begin{array}{l}\text { Pakrashi } \\
\text { et al., } 2014\end{array}$ \\
\hline $11.93-18.67$ & $\begin{array}{l}0,20,40,60,80,100 \\
\mathrm{mg} / \mathrm{Kg}\end{array}$ & $\begin{array}{l}\text { Pots with soil (treatment } \\
\text { on seeds) }\end{array}$ & Triticum aestivum & $\begin{array}{l}\text { - Increase in root and shoot length with the } \\
\text { treatment of } 60 \mathrm{mg} / \mathrm{Kg} \text { or less. } \\
\text { - Decrease in root and shoot length above } 60 \\
\text { mg/Kg concentration. }\end{array}$ & $\begin{array}{l}\text { Rafique et al., } \\
2014 .\end{array}$ \\
\hline $25 \pm 0.64$ & $\begin{array}{l}0,100,250,500,750 \\
1,000 \mathrm{mg} / \mathrm{Kg}\end{array}$ & $\begin{array}{l}\text { Pots with soil (treatment } \\
\text { on plant) }\end{array}$ & Solanum lycopersicum & $\begin{array}{l}\text { - Up to a } 250 \text { mg/Kg promoted the plant height, } \\
\text { root } \\
\text { length, and biomass. } \\
\text { - Lycopene content and fruit yield was maximum } \\
\text { for } 100 \mathrm{mg} / \mathrm{Kg} \text {. } \\
\text { - Chlorophyll concentration increases up to } 750 \\
\text { mg/Kg of nanoparticle. }\end{array}$ & $\begin{array}{l}\text { Raliya et al., } \\
2015\end{array}$ \\
\hline$<25$ & $0.01,0.1,1,10 \mathrm{mg} / \mathrm{L}$ & $\begin{array}{l}\text { Hydroponic (treatment } \\
\text { on plant) }\end{array}$ & Hydrilla verticillata & $\begin{array}{l}\text { - Increase in catalase and glutathione reductase } \\
\text { activity. } \\
\text { - } 10 \mathrm{mg} / \mathrm{L} \text { concentration has shown increase in } \\
\text { hydrogen peroxide level. }\end{array}$ & $\begin{array}{l}\text { Okupnik and } \\
\text { Pflugmacher, } \\
2016\end{array}$ \\
\hline
\end{tabular}

NP was observed to enhance the production of ROS in plants (Nair and Chung, 2014; Shaw et al., 2014). Different antioxidant compounds were observed to be significantly increased in plants treated with NP indicating the activation of the protective mechanism by plants (Shaw et al., 2014; Song et al., 2016). The genetic level study on Arabidopsis thaliana has shown that at $0.2 \mathrm{mg} / \mathrm{L}$ concentration $\mathrm{CuO} \mathrm{NP}$ does not cause any impact on the expression of genes related to oxidative stress responses, sulfur assimilation, glutathione, and proline biosynthesis (ATPS, APR, CS, GCL, P5CS1, and P5GS2), whereas, the gene expression was observed to be upregulated at higher concentrations (Nair and Chung, 2014). Atha et al. (2012) have reported a significant accumulation of oxidatively modified, mutagenic DNA lesions in different plants indicating the DNA damage as a response to $\mathrm{CuO} \mathrm{NP}$ treatment. $\mathrm{CuO}$ NP was also observed to negatively affect the photosynthetic activity by inactivating PS II reaction centers, and causing a decrease in electron transport, thylakoid number per grana, photosynthetic rate, photosynthetic pigments, transpiration rate, stomatal conductance (Perreault et al., 2014; Costa and Sharma, 2016). Phytohormones were also observed to be altered as a response to $\mathrm{CuO}$ NP (Nair and Chung, 2014; Van et al., 2016). When different varieties or plants were studied together, the influence of $\mathrm{CuO} \mathrm{NP}$ was observed to be different in genetically diverse plants (Lee et al., 2008; Adhikari et al., 
TABLE 4 | Impact of few other important metal and metal oxide NPs on plants.

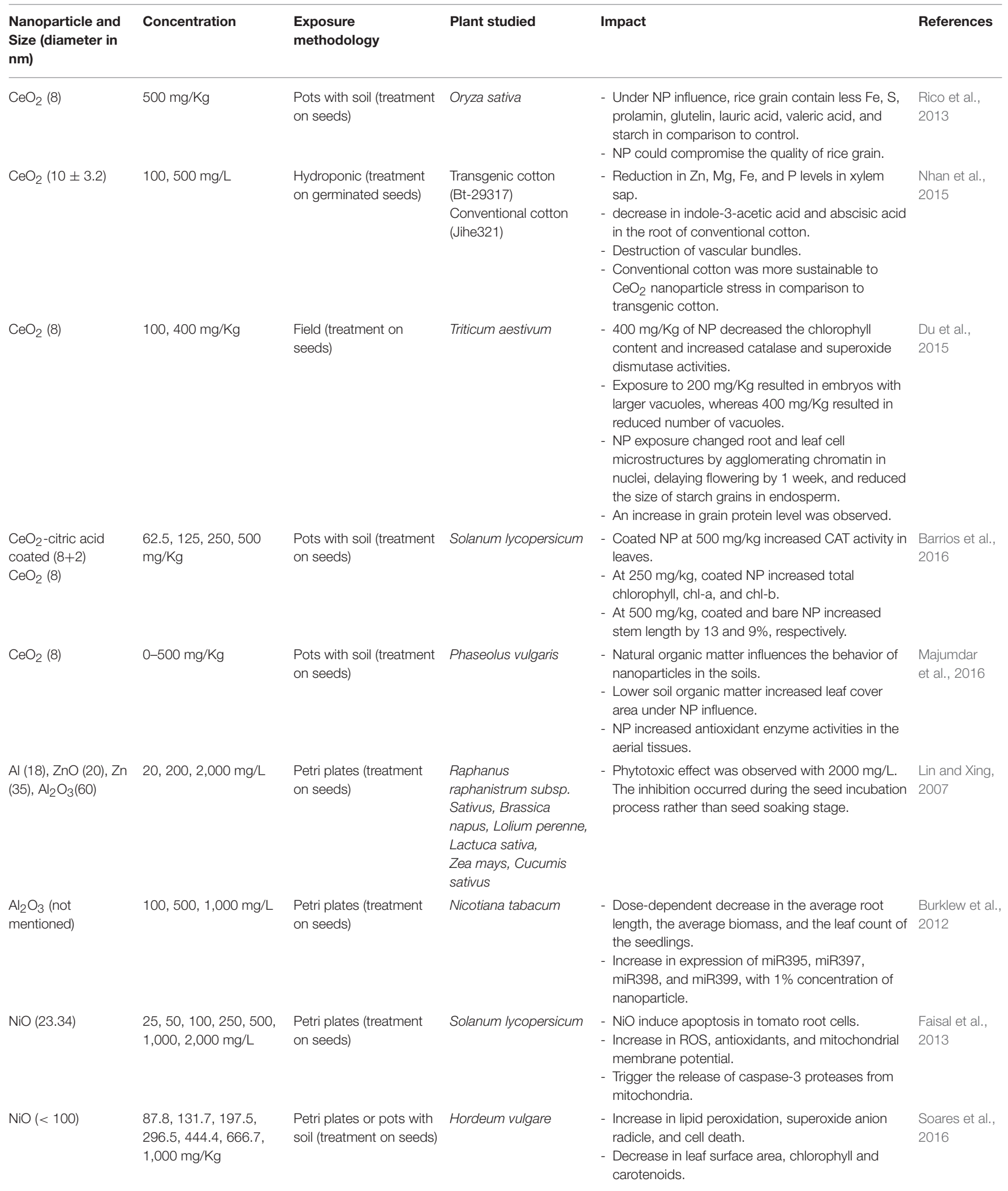




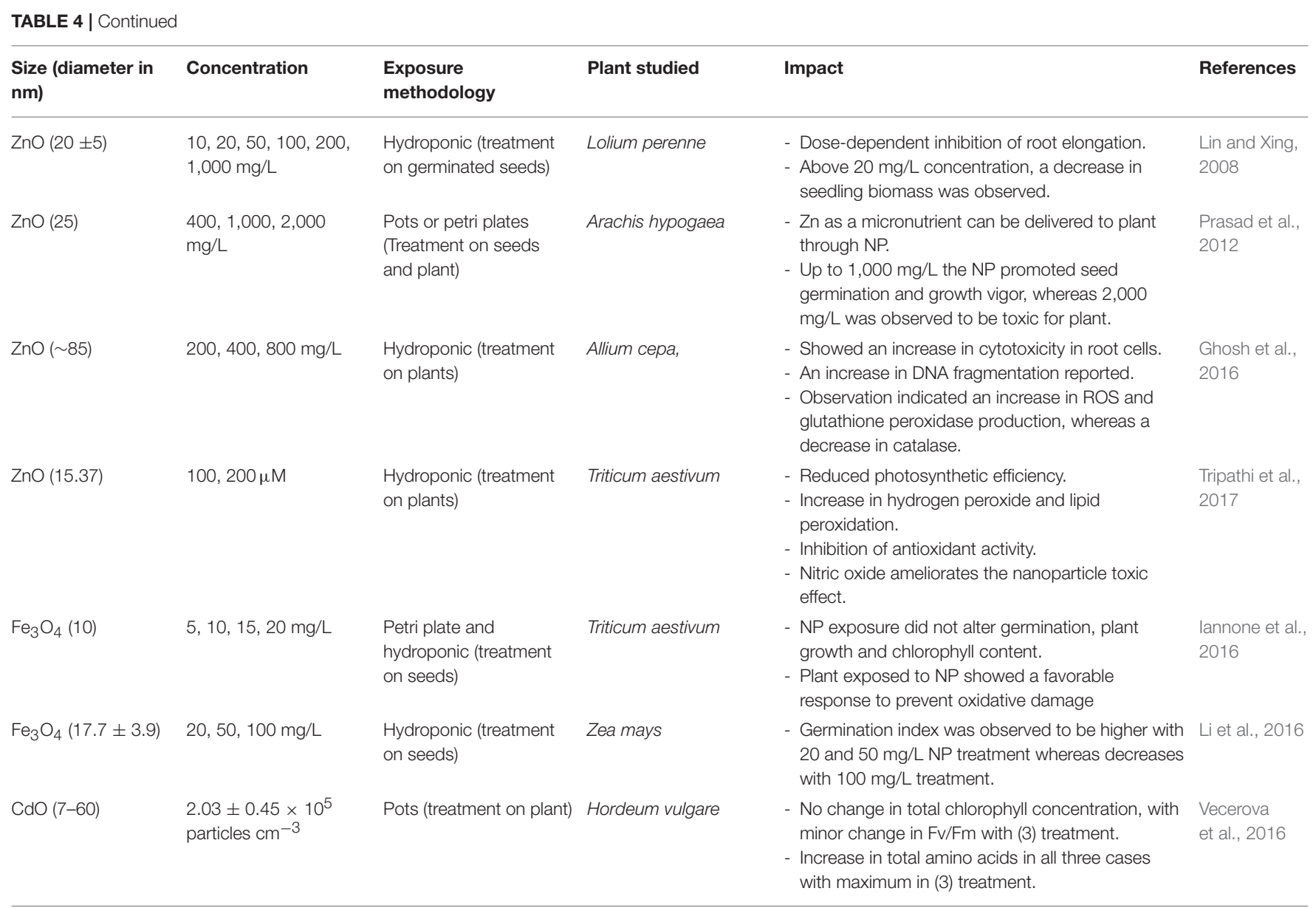

2012; Atha et al., 2012; Van et al., 2016; Wang Z. et al., 2016). A combined treatment of the plant with ultraviolet radiation and $\mathrm{CuO}$ NP were observed to significantly enhance the phytotoxic effect of CuO NP (Regier et al., 2015).

The study indicates that the $\mathrm{Cu}$ and $\mathrm{CuO}$ NPs are toxic to plants when present in concentrations higher than $0.2 \mathrm{mg} / \mathrm{L}$ and it influence the growth, physiology, and biochemistry of plants.

\section{Impact of Titanium Dioxide Nanoparticles $\left(\mathrm{TiO}_{2} \mathrm{NP}\right)$}

$\mathrm{TiO}_{2}$ NP belong to the most used nanoparticles, which are used in cosmetic and skin care products, antibacterial and cleaning air products, paints, and for decomposing organic matter in wastewater (Castiglione et al., 2011; Clément et al., 2013). Few studies have been performed to indicate the influence of $\mathrm{TiO}_{2}$ NP shows that the $\mathrm{TiO}_{2}$ NP may influence plants in positive and negative ways (Table 3 ).

Due to photocatalytic properties of titanium nanoparticles, most of the studies where $\mathrm{TiO}_{2} \mathrm{NP}$ was used at foliar level has shown a positive impacts on plant (Table 3; Gao et al., 2008; Jaberzadeh et al., 2013; Raliya et al., 2015). Spinach was observed to have more than $60 \%$ increase in the fresh weight and dry weight under the influence of $\mathrm{TiO}_{2}$ NPs (Gao et al., 2008). The author also observed the increase in amount and activity of Rubisco activase in photosynthesis. The foliar treatment of $\mathrm{TiO}_{2}$ NP also showed a better growth of the plant, increase in fruit yield, and chlorophyll concentration in Solanum lycopersicum (Raliya et al., 2015). Jaberzadeh et al. (2013) reported that $\mathrm{TiO}_{2}$ NP counteracts the water stress in Triticum aestivum by improving agronomic traits.

The smaller $\mathrm{TiO}_{2} \mathrm{NP}$ was also observed to be transported by roots, it was suggested that above diameter $140 \mathrm{~nm}, \mathrm{TiO}_{2} \mathrm{NPs}$ are no longer accumulated in roots. $\mathrm{TiO}_{2} \mathrm{NPs}$ with a diameter above $36 \mathrm{~nm}$ was observed to be accumulated in wheat root parenchyma but did not reach the stele and therefore, do not translocate to the shoot (Larue et al., 2012). A plant response to hydroponics exposure to $\mathrm{TiO}_{2}$ NPs may differ from the response to $\mathrm{TiO}_{2} \mathrm{NP}$-contaminated soil exposure. Colloidal suspensions of nanoparticles were observed to inhibit the leaf growth and transpiration via physical effects on root-water transport system (Asli and Neumann, 2009). At high concentration, $\mathrm{TiO}_{2} \mathrm{NP}$ was observed to be toxic to plants, even in soil system (Rafique et al., 2014). The phytotoxic response was found to be similar to AgNP or $\mathrm{CuO} \mathrm{NP}$, with a decrease in plant growth, mitotic index, and an increase in ROS, antioxidant activity, and genotoxicity (Table 3). The study indicates that the impact of $\mathrm{TiO}_{2} \mathrm{NP}$ on different plants depends on the concentration, ways of treatments, and size 
of NP. The study also indicated that availability of $\mathrm{TiO}_{2} \mathrm{NP}$ for a plant is different when provided through foliar treatment than through soil or water solution. The positive influence of $\mathrm{TiO}_{2}$ NP was correlated with the photocatalytic activity of Ti, but the mechanism behind this interaction is so far not understood.

\section{Some of the Notable Studies on the Impact of Other Metal and Metal Oxide Nanoparticles}

Several other nanoparticles are used in different industries to improve the product/service quality. Some of these nanoparticles are used in plant study to observe their effects on plants (Table 4). Cerium dioxide nanoparticles $\left(\mathrm{CeO}_{2} \mathrm{NP}\right)$ are mainly used in automotive industries and semiconductor industry, and can interfere with the cell metabolism due to its oxidative properties. $\mathrm{CeO}_{2} \mathrm{NP}$ was observed to behave differently in tomato plant when coated with citric acid, in comparison to bare $\mathrm{CeO}_{2} \mathrm{NP}$ (Barrios et al., 2016). Coated NP was observed to increase chlorophyll concentration, stem length, and catalase activity. The change in behavior of NP can be attributed to different chemical properties and size of the nanoparticle due to the presence of the cap. A different study using $\mathrm{CeO}_{2}$ in the presence of soil organic matter confirms that the surrounding and composition influences the behavior of nanoparticle for plant (Majumdar et al., 2016). Field and soil experiments with wheat and rice have shown that application of $\mathrm{CeO}_{2} \mathrm{NP}$ compromised the quality of grain (Rico et al., 2013; Du et al., 2015). The hydroponic experiment performed on cotton shows that $\mathrm{CeO}_{2} \mathrm{NP}$ destroys the vascular bundles in cotton with a decrease in indole-3acetic acid and abscisic acid (Nhan et al., 2015). The authors also observed that conventional cotton was more sustainable to $\mathrm{CeO}_{2} \mathrm{NP}$ stress in comparison to transgenic cotton. Nickel oxide nanoparticle (NiO NP) was observed to induce ROS, and antioxidant molecules whereas, it was observed to reduce the concentration of plant pigments (Faisal et al., 2013; Soares et al., 2016). Zinc ( $\mathrm{Zn}$ ) and Zinc oxide nanoparticles (ZnO NP) affected plant germination and had negative effects on root elongation (Lin and Xing, 2007, 2008). ZnO NP was also observed to reduce photosynthetic efficiency and antioxidant activity whereas it induces the ROS production in the wheat plant (Tripathi et al., 2017). DNA fragmentation was also observed due to $\mathrm{ZnO}$ NP toxicity in Allium cepa (Ghosh et al., 2016). Treatment of $\mathrm{ZnO} \mathrm{NP}$ at 1,000 ppm concentration was observed to promote seed germination and seedling vigor, and in turn showed early establishment in soil manifested by early flowering and higher leaf chlorophyll content, but the higher concentration of $\mathrm{ZnO}$ $\mathrm{NP}$ at 2,000 ppm was observed to have negative and toxic effect on the growth and yield of peanut (Prasad et al., 2012). In turn, Stampoulis et al. (2009) did not observe any significant effects of $\mathrm{ZnO}$ on Cucurbita pepo in studied concentration. Burklew et al. (2012) observed an increase in the expression of different stress related micro RNA in tobacco plant when exposed to Aluminum oxide nanoparticle $\left(\mathrm{Al}_{2} \mathrm{O}_{3} \mathrm{NP}\right)$. $\mathrm{NiO} \mathrm{NP}$ was observed to induce the apoptosis and promote the release of caspase- 3 proteases from mitochondria (Faisal et al., 2013). The authors also observed that nitric oxide ameliorates the toxic effect of nanoparticle. The
Iron oxide nanoparticles $\left(\mathrm{Fe}_{3} \mathrm{O}_{4} \mathrm{NP}\right)$ at lower concentrations were observed to have beneficiary impact on plant and improves germination (Iannone et al., 2016; Li et al., 2016), whereas cadmium oxide nanoparticles (CdO NP) at low concentration were found to increase total amino acid production without influencing photosynthetic parameters (Vecerova et al., 2016)

The study clearly indicates that the presence of industrial nanoparticles in the environment influence the plants. Despite the positive effects of some NPs, the studies clearly indicate that all kinds of nanoparticles represent the possible environmental risk.

\section{MECHANISM OF NANOPARTICLE-PLANT INTERACTION}

Based on the scientific works performed, it is evident that most of the nanoparticles are toxic to the plants in high concentration. It is hypothesized that, for exhibiting the toxic effect the uptake of nanoparticles by plant and their translocation into different tissues is needed. Further, based on their transportation, properties, and reactivity, the nanoparticles may interfere with different metabolic activity to produce an impact on plants.

\section{Nanoparticle Uptake}

The nanoparticles when present in higher concentrations are observed to damage the plant cell wall and plasma membrane, thus penetrating it and interacting with the different plant's processes (Mazumdar and Ahmed, 2011; Mirzajani et al., 2013). Nanoparticles can enter plant tissue either through root or the above ground parts including root junctions and wounds. For uptake and translocation nanoparticles has to go through various chemical and physiological barriers. When nanoparticles interact with plant, cell wall is the first barrier it has to cross. Plant cell walls are a structure which is composed of cellulose which permits the entry of small particles and restricting the larger one, therefore smaller nanoparticles can go through this layer in a comparatively easy way in respect to larger nanoparticles. The size exclusion limit for the plant cell wall is between 5 and $20 \mathrm{~nm}$ (Dietz and Herth, 2011). Some of the nanoparticles have been reported to induce the formation of larger pores in cell wall which further facilitate the entry of large nanoparticles (Navarro et al., 2008; Kurepa et al., 2010). From the cell wall the nanoparticles may move through endocytosis (Etxeberria et al., 2006), and further, through the symplastic transport, it may travel to different plant tissues (Ma et al., 2010). Recently, Wong et al. (2016) have proposed a mathematical model which indicates lipid exchange mechanism for nanoparticle transport inside the plant cells. The study indicated that size, magnitude, and zeta potentials are key in determining the transport of nanoparticle inside the plant.

\section{Nanoparticle-Plant Interaction Pathways}

Nanoparticles may interfere with plant metabolism in several ways, such as, by providing micronutrients (Liu and Lal, 2015), regulation of genes (Nair and Chung, 2014), or interfering with different oxidative processes in plants which results in oxidative burst (Figure 2; Hossain et al., 2015). From the previous part 


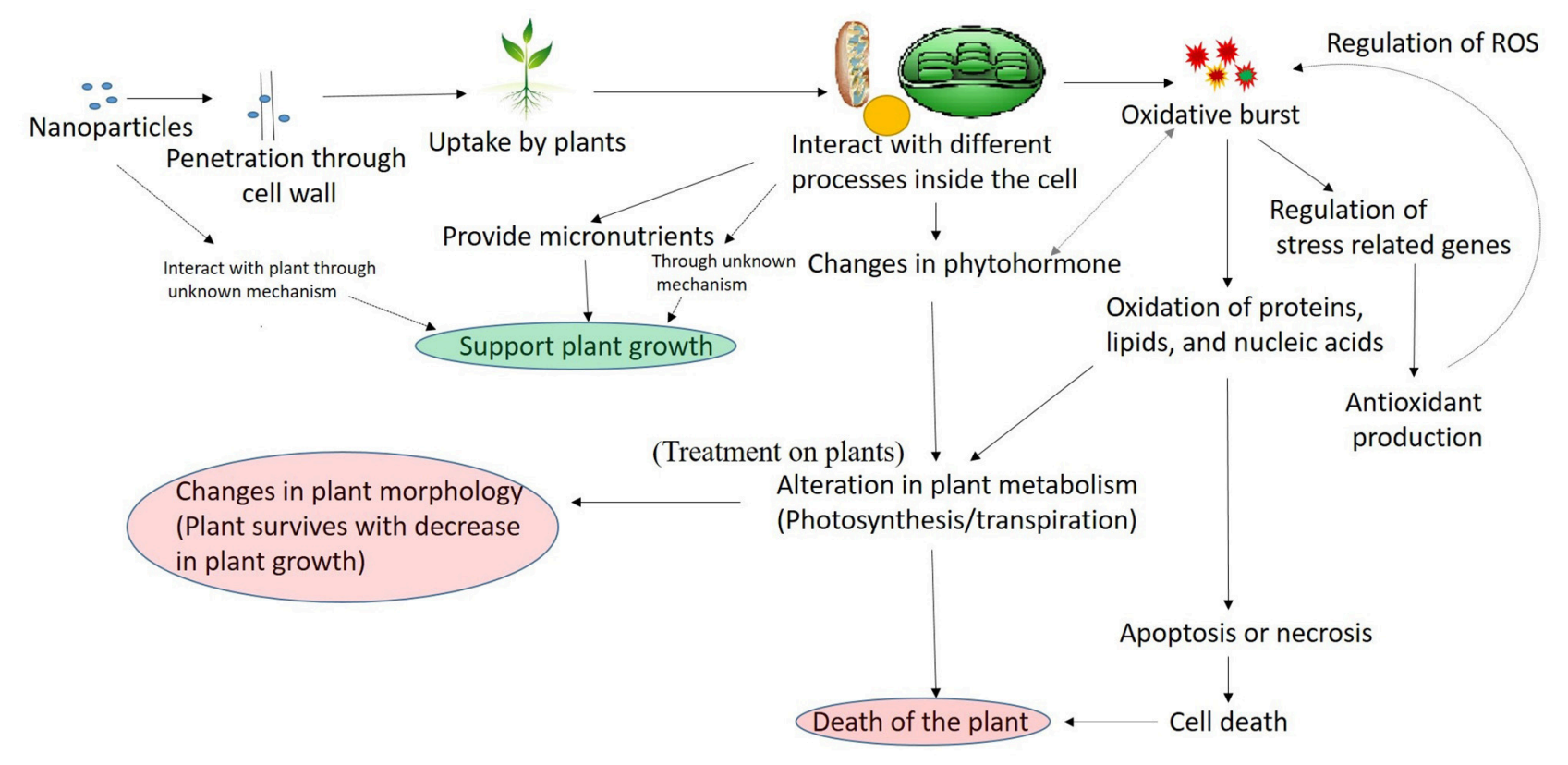

FIGURE 2 | A general mechanism of nanoparticles interaction with plant.

of this article, it is clear that several nanoparticles when present in excess results into ROS production, and interfere with the oxidative mechanism, whereas other types of interactive pathways are not deciphered and there is still much work needed to understand the other pathways. Therefore, the oxidative part is elaborated in Figure 2 and further discussed here.

The entered nanoparticles can interfere with electron transport chain of mitochondria and chloroplast, which may results into the oxidative burst, observed by the increase in ROS concentration (Dimkpa et al., 2013; Faisal et al., 2013; Jiang et al., 2014; Pakrashi et al., 2014; Cvjetko et al., 2017). It has been previously reported that under influence of different stress factors, the rate of carbon fixation is limited, which causes an increase in photoinhibition potentially steering the photosystem toward overproduction of superoxide anion radicals and $\mathrm{H}_{2} \mathrm{O}$ (Foyer and Noctor, 2005). Once the ROS is produced as the result of nanoparticle interaction, it is known that it interacts with almost all cellular components producing protein modifications, lipid peroxidation, and damage to DNA (Van Breusegem and Dat, 2006). Several reports have shown an increase in lipid peroxidation and DNA damage in plantsnanoparticle interaction (Atha et al., 2012; Belava et al., 2017; Cvjetko et al., 2017; Saha and Dutta Gupta, 2017), which confirms that plant interaction with nanoparticles leads into lipid peroxidation. The increased production of ROS can either induce apoptosis or necrosis (Van Breusegem and Dat, 2006; Rastogi and Pospísil, 2012; Faisal et al., 2013), which results in plant cell death. Despite their destructive activity, ROS are also known to have a signaling role in a variety of cellular processes including tolerance to environmental stresses (Sharma et al., 2012). The destructive or signaling role of ROS depends on the equilibrium between
ROS production and scavenging. Due to the multifunctional roles of ROS, the cells have developed a strong antioxidant mechanism to precisely control the level of ROS. The antioxidant mechanism contains the production of enzymatic (superoxide dismutase, catalase, and guaiacol peroxidase) and non-enzymatic (Ascorbate, glutathione, carotenoids, tocopherols, and phenolics) molecules (Sharma et al., 2012). To cope up with the stress plants increases the production of antioxidant molecules (Rastogi and Pospísil, 2010; Sharma et al., 2012). Several reports have shown the increased production of the antioxidant molecule in the plant under the influence of nanoparticles (Faisal et al., 2013; Jiang et al., 2014; Costa and Sharma, 2016), which confirms the regulation of antioxidant system as a response to nanoparticle interaction with plant. If the antioxidant produced are unable to control the ROS, The ROS oxidized the cell macromolecules and results into the death of the cell by apoptosis or necrosis (Sharma et al., 2012), which ultimately results in the death of the plant. The recent reports have also shown that phytohormone plays an important role in plant stress response signaling (O’Brien and Benková, 2013). The hormonal control of plant development and stress adaptation is considered to be the outcome of a complex network of synergistic and antagonistic interactions between various hormones. The ROS are also linked to hormonal signaling in a complex manner and influence each other activity (Kwak et al., 2006). Different hormonal pathways are known to be upregulated or downregulated in response to different type of stresses (O’Brien and Benková, 2013). The observed increase in cytokinin level in Capsicum annuum as a response to AgNP stress, and a decreases in IAA and $\mathrm{ABA}$ in a cotton plant in response to $\mathrm{CuO} \mathrm{NP}$ indicates that nanoparticle influence the hormonal balance in plants, thus 
affecting the plant metabolism. Therefore, it can be said that the toxic effect of nanoparticles in the plant is mainly mediated through ROS.

The electron transport chain in mitochondria and chloroplast operates in aerobic environment, and thus the excess production of ROS impact the processes (Foyer and Shigeoka, 2011). Photosynthesis is also considered to be a good measure of overall performance of plants (Kalaji et al., 2014). It is the only energy input in plants and thereby impacts all aspects of plant metabolism and physiology. Thus, the measurement of photosynthetic pigment and activity is a good measure to access the impact of stress factors. Different reports have shown that the nanoparticles influence the photosynthetic pigment concentration and its activity in plants (Qian et al., 2013; Perreault et al., 2014; Tripathi et al., 2017). A very high concentration of nanoparticles may severely affect the photosynthesis which may result in plant growth suppression or plant death. Several reports have observed significant decrease in plant growth as the result of nanoparticle exposure (For reference see Tables 1-4). Root is the primary organ for up taking nanoparticles from soil/water are adversely affected in comparison to shoot in some plants (Pokhrel and Dubey, 2013; Qian et al., 2013; Shaw et al., 2014; Tripathi et al., 2017; Vinković et al., 2017).

\section{CONCLUSION AND FUTURE PERSPECTIVE}

In modern age, nanoparticles are used intensively and becoming a part of the human life. But due to the need of present and modern life, environment cannot be neglected. It is evident from the studies that metal and metal oxides nanoparticles in excess are harmful to plants, whereas, when present in traces it can be beneficial for plants. Therefore, the increasing concentration of nanoparticles in the environment may cause a serious impact on agriculture in future. This review took out clear information

\section{REFERENCES}

Adams, J., Wright, M., Wagner, H., Valiente, J., Britt, D., and Anderson, A. (2017). $\mathrm{Cu}$ from dissolution of $\mathrm{CuO}$ nanoparticles signals changes in root morphology. Plant Physiol. Biochem. 110, 108-117. doi: 10.1016/j.plaphy.2016.08.005

Adhikari, T., Kundu, S., Biswas, A. K., Tarafdar, J. C., and Rao, A. S. (2012). Effect of copper oxide nano particle on seed germination of selected crops. J. Agric. Sci. Technol. A 2, 815-823. doi: 10.17265/2161-6256/2012.06A.009

Asli, S., and Neumann, P. M. (2009). Colloidal suspensions of clay or titanium dioxide nanoparticles can inhibit leaf growth and transpiration via physical effects on root water transport. Plant Cell Environ. 32, 577-584. doi: 10.1111/j.1365-3040.2009.01952.x

Atha, D. H., Wang, H., Petersen, E. J., Cleveland, D., Holbrook, R. D., Jaruga, P., et al. (2012). Copper oxide nanoparticle mediated DNA damage in terrestrial plant models. Environ. Sci. Technol. 46, 1819-1827. doi: 10.1021/es202660k

Auffan, M., Rose, J., Bottero, J. Y., Lowry, G. V., Jolivet, J. P., and Wiesner, M. R. (2009). Towards a definition of inorganic nanoparticles from an environmental, health and safety perspective. Nat. Nanotechnol. 4, 634-641. doi: 10.1038/nnano.2009.242

Barrios, A. C., Rico, C. M., Trujillo-Reyes, J., Medina-Velo, I. A., Peralta-Videa, J. R., and Gardea-Torresdey, J. L. (2016). Effects of uncoated and citric from known literature to shows an influence of metal and metal oxide nanoparticle on the plant, but there are needs of research to understand the molecular mechanism of plant nanoparticle interaction. There are few research showing the beneficial role of metal and metal oxide nanoparticles in agriculture, but the mechanism at large extant are not understood, and the studies are in its primitive stage. Therefore, a lot of study is needed before bringing the nanoparticles to the field. Most of the study performed shows morphological variation caused to plants due to metal and metal oxide nanoparticles. The study also shows a clear lack of standardization for nanoparticles phytotoxic assay. Therefore, research is needed to be done in the area to understand the impact of metal and metal oxides nanoparticle on plant physiology and molecular biology.

Nanoscience is attracting lot of research funding, some of which need to be diverted for the awareness of the people about the proper disposal of nanoparticle products. The research is also needed to be performed in the area of remediation of nanoparticle from agriculture soil and wastewater.

\section{AUTHOR CONTRIBUTIONS}

$\mathrm{AR}, \mathrm{MB}$, and $\mathrm{MZ}$ discussed the idea. $\mathrm{AR}, \mathrm{MZ}$, OS, $\mathrm{MB}$, and $\mathrm{XH}$ prepared the manuscript. HK and SM read and improved the manuscript, also helped AR in preparing the tables. AR prepared the figures. All authors read and worked on the scientific language of the manuscript.

\section{ACKNOWLEDGMENTS}

This work was supported by the research project of the Slovak Research and Development Agency under the project APVV15-0721, VEGA 1/0923/16, and National Science Centre Poland, under the project UMO-2016/21/B/ST10/02271. AR thanks, Slovak Academic Information Agency (SAIA) for providing National Scholarship for research in the year 2017.

acid coated cerium oxide nanoparticles, bulk cerium oxide, cerium acetate, and citric acid on tomato plants. Sci. Total Environ. 563-564, 956-964. doi: 10.1016/j.scitotenv.2015.11.143

Belava, V. N., Panyuta, O. O., Yakovleva, G. M., Pysmenna, Y. M., and Volkogon, M. V. (2017). The effect of silver and copper nanoparticles on the WheatPseudocercosporella herpotrichoides pathosystem. Nanoscale Res. Lett. 12:250. doi: 10.1186/s11671-017-2028-6

Berahmand, A. A., Ghafariyan-Panahi, A., Sahabi, H., Feizi, H., RezvaniMoghaddam, P., Shahtahmassebi, N., et al. (2012). Effects silver nanoparticles and magnetic field on growth of fodder maize (Zea mays L.). Biol. Trace Elem. Res. 149, 419-424. doi: 10.1007/s12011-012-9434-5

Boxall, P., Purcell, J., and Wright, P. M. (eds.). (2008). "Human resource management: scope, analysis and significance" in The Oxford Handbook of Human Resource Management (Oxford: Oxford University Press), 1-18. doi: 10.1093/oxfordhb/9780199547029.003.0001

Burklew, C. E., Ashlock, J., Winfrey, W. B., and Zhang, B. (2012). Effects of aluminum oxide nanoparticles on the growth, development, and microRNA expression of tobacco (Nicotiana tabacum). PLoS ONE 7:e34783. doi: 10.1371/journal.pone.0034783

Castiglione, M. R., Giorgetti, L., Geri, C., and Cremonini, R. (2011). The effects of nano-TiO2 on seed germination, development and mitosis of root tip cells 
of Vicia narbonensis L. and Zea mays L. J. Nanoparticle Res. 13, 2443-2449. doi: 10.1007/s11051-010-0135-8

Clément, L., Hurel, C., and Marmier, N. (2013). Toxicity of TiO2 nanoparticles to cladocerans, algae, rotifers and plants - effects of size and crystalline structure. Chemosphere 90, 1083-1090. doi: 10.1016/j.chemosphere.2012.09.013

Costa, M. V. J. D., and Sharma, P. K. (2016). Effect of copper oxide nanoparticles on growth, morphology, photosynthesis, and antioxidant response in Oryza sativa. Photosynthetica 54, 110-119. doi: 10.1007/s11099-015-0167-5

Cvjetko, P., Milošić, A., Domijan, A. M., Vinković-Vrček, I., Tolić, S., PeharecŠtefanić, P., et al. (2017). Toxicity of silver ions and differently coated silver nanoparticles in Allium cepa roots. Ecotoxicol. Environ. Saf. 137, 18-28. doi: 10.1016/j.ecoenv.2016.11.009

De la Torre Roche, R., Servin, A., Hawthorne, J., Xing, B., Newman, L. A., Ma, X., et al. (2015). Terrestrial trophic transfer of bulk and nanoparticle $\mathrm{La}_{2} \mathrm{O}_{3}$ does not depend on particle size. Environ. Sci. Technol. 49, 11866-11874. doi: 10.1021 /acs.est.5b02583

Demir, E., Kaya, N., and Kaya, B. (2014). Genotoxic effects of zinc oxide and titanium dioxide nanoparticles on root meristem cells of Allium cepa by comet assay. Turk. J. Biol. 38, 31-39. doi: 10.3906/biy-1306-11

Dietz, K.-J., and Herth, S. (2011). Plant nanotoxicology. Trends Plant Sci. 16, 582-589. doi: 10.1016/j.tplants.2011.08.003

Dimkpa, C. O., McLean, J. E., Martineau, N., Britt, D. W., Haverkamp, R., and Anderson, A. J. (2013). Silver nanoparticles disrupt wheat (Triticum aestivum L.) growth in a sand matrix. Environ. Sci. Technol. 47, 1082-1090. doi: $10.1021 /$ es302973y

Du, W., Gardea-Torresdey, J. L., Ji, R., Yin, Y., Zhu, J., Peralta-Videa, J. R., et al. (2015). Physiological and biochemical changes imposed by $\mathrm{CeO}_{2}$ nanoparticles on wheat: a life cycle field study. Environ. Sci. Technol. 49, 11884-11893. doi: 10.1021/acs.est.5b03055

Dumont, E., Johnson, A. C., Keller, V. D., and Williams, R. J. (2015). Nano silver and nano zinc-oxide in surface waters - exposure estimation for Europe at high spatial and temporal resolution. Environ. Pollut. 196, 341-349. doi: 10.1016/j.envpol.2014.10.022

El-Temsah, Y. S., and Joner, E. J. (2012). Ecotoxicological effects on earthworms of fresh and aged nano-sized zero-valent iron (nZVI) in soil. Chemosphere 89, 76-82. doi: 10.1016/j.chemosphere.2012.04.020

Etxeberria, E., Gonzalez, P., Pozueta-Romero, J., and Romero, J. P. (2006). Fluid phase endocytic uptake of artificial nano-spheres and fluorescent quantum dots by sycamore cultured cells: evidence for the distribution of solutes to different intracellular compartments. Plant Signal. Behav. 1, 196-200. doi: $10.4161 /$ psb.1.4.3142

Faisal, M., Saquib, Q., Alatar, A. A., Al-Khedhairy, A. A., Hegazy, A. K., and Musarrat, J. (2013). Phytotoxic hazards of NiO-nanoparticles in tomato: a study on mechanism of cell death. J. Hazard. Mater. 250-251, 318-332. doi: 10.1016/j.jhazmat.2013.01.063

Feng, Y., Cui, X., He, S., Dong, G., Chen, M., Wang, J., et al. (2013). The role of metal nanoparticles in influencing arbuscular mycorrhizal fungi effects on plant growth. Environ. Sci. Technol. 47, 9496-9504. doi: 10.1021/es402109n

Foyer, C. H., and Noctor, G. (2005). Redox homeostasis and antioxidant signaling: a metabolic interface between stress perception and physiological responses. Plant Cell 17, 1866-1875. doi: 10.1105/tpc.105.033589

Foyer, C. H., and Shigeoka, S. (2011). Understanding oxidative stress and antioxidant functions to enhance photosynthesis. Plant Physiol. 155, 93-100. doi: 10.1104/pp.110.166181

Fraceto, L. F., Grillo, R., de Medeiros, G. A., Scognamiglio, V., Rea, G., and Bartolucci, C. (2016). Nanotechnology in agriculture: which innovation potential does it have? Front. Environ. Sci. 4:20. doi: 10.3389/fenvs.2016.00020

Gao, F., Liu, C., Qu, C., Zheng, L., Yang, F., Su, M., et al. (2008). Was improvement of spinach growth by nano- $\mathrm{TiO}_{2}$ ) treatment related to the changes of Rubisco activase? Biometals 21, 211-217. doi: 10.1007/s10534-007-9110-y

Ghosh, M., Jana, A., Sinha, S., Jothiramajayam, M., Nag, A., Chakraborty, A., et al. (2016). Effects of $\mathrm{ZnO}$ nanoparticles in plants: cytotoxicity, genotoxicity, deregulation of antioxidant defenses, and cell-cycle arrest. Mutat. Res. Genet. Toxicol. Environ. Mutagen. 807, 25-32. doi: 10.1016/j.mrgentox.2016.07.006

Hadioui, M., Merdzan, V., and Wilkinson, K. J. (2015). Detection and characterization of $\mathrm{ZnO}$ nanoparticles in surface and waste waters using single particle ICPMS. Environ. Sci. Technol. 49, 6141-6148. doi: 10.1021/acs.est.5b00681
Hawthorne, J., De la Torre Roche, R., Xing, B., Newman, L. A., Ma, X., Majumdar, S., et al. (2014). Particle-size dependent accumulation and trophic transfer of cerium oxide through a terrestrial food chain. Environ. Sci. Technol. 48, 13102-13109. doi: 10.1021/es503792f

Hawthorne, J., Musante, C., Sinha, S. K., and White, J. C. (2012). Accumulation and phytotoxicity of engineered nanoparticles to Cucurbita pepo. Int. J. Phytoremediation 14, 429-442. doi: 10.1080/15226514.2011.620903

Helaly, M. N., El-Hoseiny, H., El-Sheery, N. I., Rastogi, A., and Kalaji, H. M. (2017). Regulation and physiological role of silicon in alleviating drought stress of mango. Plant Physiol. Biochem. 118, 31-44. doi: 10.1016/j.plaphy.2017. 05.021

Hossain, Z., Mustafa, G., and Komatsu, S. (2015). Plant responses to nanoparticle stress. Int. J. Mol. Sci. 16, 26644-26653. doi: 10.3390/ijms161125980

Iannone, M. F., Groppa, M. D., de Sousa, M. E., van Raap, M. B. F., and Benavides, M. P. (2016). Impact of magnetite iron oxide nanoparticles on wheat (Triticum aestivum L.) development: evaluation of oxidative damage. Environ. Exp. Bot. 131, 77-88. doi: 10.1016/j.envexpbot.2016.07.004

Jaberzadeh, A., Moaveni, P., Moghadam, H. R. T., and Zahedi, H. (2013). Influence of bulk and nanoparticles titanium foliar application on some agronomic traits, seed gluten and starch contents of wheat subjected to water deficit stress. Not. Bot. Horti Agrobo. 41, 201-207. doi: 10.15835/nbha4119093

Jasim, B., Thomas, R., Mathew, J., and Radhakrishnan, E. K. (2016). Plant growth and diosgenin enhancement effect of silver nanoparticles in Fenugreek (Trigonella foenum-graecum L.). Saudi Pharm. J. 25, 443-447. doi: 10.1016/j.jsps.2016.09.012

Jiang, H. S., Qiu, X. N., Li, G. B., Li, W., and Yin, L. Y. (2014). Silver nanoparticles induced accumulation of reactive oxygen species and alteration of antioxidant systems in the aquatic plant Spirodela polyrhiza. Environ. Toxicol. Chem. 33, 1398-1405. doi: 10.1002/etc.2577

Jo, Y. K., Kim, B. H., and Jung, G. (2009). Antifungal activity of silver ions and nanoparticles on phytopathogenic fungi. Plant Dis. 93, 1037-1043. doi: 10.1094/PDIS-93-10-1037

Johansson, M., Pell, M., and Stenström, J. (1998). Kinetics of SubstrateInduced Respiration (SIR) and denitrification: applications to a soil amended with silver. Ambio 27, 40-44.

Joner, E. J., Hartnik, T., and Amundsen, C. E. (2008). Norwegian Pollution Control Authority Report no. TA 2304/2007. Bioforsk; Environmental fate and ecotoxicity of engineered nanoparticles, 1-64.

Judy, J. D., Unrine, J. M., Rao, W., and Bertsch, P. M. (2012). Bioaccumulation of gold nanomaterials by Manduca sexta through dietary uptake of surface contaminated plant tissue. Environ. Sci. Technol. 46, 12672-12678. doi: $10.1021 / \mathrm{es} 303333 \mathrm{w}$

Kalaji, H. M., Schansker, G., Ladle, R. J., Goltsev, V., Bosa, K., Allakhverdiev, S. I., et al. (2014). Frequently asked questions about in vivo chlorophyll fluorescence: practical issues. Photosyn. Res. 122, 121-158. doi: 10.1007/s11120-014-0024-6

Kasana, R. C., Panwar, N. R., Kaul, R. K., and Kumar, P. (2017). Biosynthesis and effects of copper nanoparticles on plants. Environ. Chem. Lett. 15, 233-240. doi: 10.1007/s10311-017-0615-5

Keller, A. A., and Lazareva, A. (2014). Predicted releases of engineered nanomaterials: from global to regional to local. Environ. Sci. Technol. Lett. 1, 65-70. doi: 10.1021/ez400106t

Khaydarov, R. R., Khaydarov, R. A., Gapurova, O., Estrin, Y., Evgrafova, S., Scheper, T., et al. (2009). "Antimicrobial effects of silver nanoparticles synthesized by an electrochemical method," in Nanostructured Material for Advanced Technological Applications, NATO Science for Peace and Security Series B: Physics and Biophysics, Part 5, eds J. P. Reithmaier, P. Petkov, W. Kulisch, and C. Popov (Dordrecht: Springer), 215-218.

Krishnaraj, C., Ramachandran, R., Mohan, K., and Kalaichelvan, P. T. (2012). Optimization for rapid synthesis of silver nanoparticles and its effect on phytopathogenic fungi. Spectrochim. Acta A Mol. Biomol. Spectrosc. 93, 95-99. doi: 10.1016/j.saa.2012.03.002

Kurepa, J., Paunesku, T., Vogt, S., Arora, H., Rabatic, B. M., Lu, J., et al. (2010). Uptake and distribution of ultrasmall anatase $\mathrm{TiO}_{2}$ Alizarin red S nanoconjugates in Arabidopsis thaliana. Nano Lett. 10, 2296-2302. doi: $10.1021 / \mathrm{nl} 903518 \mathrm{f}$

Kwak, J. M., Nguyen, V., and Schroeder, J. I. (2006). The role of reactive oxygen species in hormonal responses. Plant Physiol. 141, 323-329. doi: 10.1104/pp.106.079004 
Lahiani, M. H., Chen, J., Irin, F., Puretzky, A. A., Green, M. J., and Khodakovskaya, M. V. (2015). Interaction of carbon nanohorns with plants: uptake and biological effects. Carbon N. Y. 81, 607-619. doi: 10.1016/j.carbon.2014. 09.095

Landa, P., Cyrusova, T., Jerabkova, J., Drabek, O., Vanek, T., and Podlipna, R. (2016). Effect of metal oxides on plant germination: phytotoxicity of nanoparticles, bulk materials, and metal ions. Water Air Soil 227, 448. doi: 10.1007/s11270-016-3156-9

Larue, C., Laurette, J., Herlin-Boime, N., Khodja, H., Fayard, B., Flank, A. M., et al. (2012). Accumulation, translocation and impact of $\mathrm{TiO}_{2}$ nanoparticles in wheat (Triticum aestivum spp.): influence of diameter and crystal phase. Sci. Total Environ. 431, 197-208. doi: 10.1016/j.scitotenv.2012.04.073

Lee, W. M., An, Y. J., Yoon, H., and Kweon, H. S. (2008). Toxicity and bioavailability of copper nanoparticles to the terrestrial plants mung bean (Phaseolus radiatus) and wheat (Triticum aestivum): plant agar test for water-insoluble nanoparticles. Environ. Toxicol. Chem. 27, 1915-1921. doi: $10.1897 / 07-481.1$

Levard, C., Hotze, E. M., Lowry, G. V., and Brown, G. E. Jr. (2012). Environmental transformations of silver nanoparticles: impact on stability and toxicity. Environ. Sci. Technol. 46, 6900-6914. doi: 10.1021/es2037405

Li, J., Hu, J., Ma, C., Wang, Y., Wu, C., Huang, J., et al. (2016). Uptake, translocation and physiological effects of magnetic iron oxide $(\gamma-$ $\mathrm{Fe}_{2} \mathrm{O}_{3}$ ) nanoparticles in corn (Zea mays L.). Chemosphere 159, 326-334. doi: 10.1016/j.chemosphere.2016.05.083

Lin, D., and Xing, B. (2007). Phytotoxicity of nanoparticles: inhibition of seed germination and root growth. Environ. Pollut. 150, 243-250. doi: 10.1016/j.envpol.2007.01.016

Lin, D., and Xing, B. (2008). Root uptake and phytotoxicity of $\mathrm{ZnO}$ nanoparticles. Environ. Sci. Technol. 42, 5580-5585. doi: 10.1021/es800422x

Liu, J., and Hurt, R. H. (2010). Ion release kinetics and particle persistence in aqueous nano-silver colloids. Environ. Sci. Technol. 44, 2169-2175. doi: $10.1021 /$ es 9035557

Liu, R., and Lal, R. (2015). Potentials of engineered nanoparticles as fertilizers for increasing agronomic productions. Sci. Total Environ. 514, 131-139. doi: 10.1016/j.scitotenv.2015.01.104

Ma, X., Geisler-Lee, J., Deng, Y., and Kolmakov, A. (2010). Interactions between engineered nanoparticles (ENPs) and plants: phytotoxicity, uptake and accumulation. Sci. Total Environ. 408, 3053-3061. doi: 10.1016/j.scitotenv.2010.03.031

Mahdi, K. N. M., Petersc, R. J. B., Klumpp, E., Bohme, S., Ploeg, M. V. D., Ritsema, C., et al. (2017). Silver nanoparticles in soil: aqueous extraction combined with single-particle ICP-MS for detection and characterization. Environ. Nanotechnol. Monit. Manage 7, 24-33. doi: 10.1016/j.enmm.2016.12.002

Majumdar, S., Peralta-Videa, J. R., Trujillo-Reyes, J., Sun, Y., Barrios, A. C., Niu, G., et al. (2016). Soil organic matter influences cerium translocation and physiological processes in kidney bean plants exposed to cerium oxide nanoparticles. Sci. Total Environ. 569-570, 201-211. doi: 10.1016/j.scitotenv.2016.06.087

Martin-Ortigosa, S., Peterson, D. J., Valenstein, J. S., Lin, V. S., Trewyn, B. G., Lyznik, L. A., et al. (2014). Mesoporous silica nanoparticle-mediated intracellular cre protein delivery for maize genome editing via loxP site excision. Plant Physiol. 164, 537-547. doi: 10.1104/pp.113.233650

Maruyama, C. R., Guilger, M., Pascoli, M., Bileshy-José, N., Abhilash, P. C., Fraceto, L. F., et al. (2016). Nanoparticles based on chitosan as carriers for the combined herbicides imazapic and imazapyr. Sci. Rep. 6:19768. doi: 10.1038/srep19768

Maurer-Jones, M. A., Gunsolus, I. L., Murphy, C. J., and Haynes, C. L. (2013). Toxicity of engineered nanoparticles in the environment. Anal. Chem. 85, 3036-3049. doi: 10.1021/ac303636s

Mazumdar, H., and Ahmed, G. U. (2011). Phytotoxicity effect of silver nanoparticles on Oryza sativa. Int. J. ChemTech. Res. 3, 1494-1500. Available online at: http://sphinxsai.com/Vol.3No.3/Chem/chVol.3No.3J_S11_8.htm

Mirzajani, F., Askari, H., Hamzelou, S., Farzaneh, M., and Ghassempour, A. (2013). Effect of silver nanoparticles on Oryza sativa L. and its rhizosphere bacteria. Ecotoxicol. Environ. Saf. 88, 48-54. doi: 10.1016/j.ecoenv.2012.10.018

Nair, P. M., and Chung, I. M. (2014). Impact of copper oxide nanoparticles exposure on Arabidopsis thaliana growth, root system development, root lignificaion, and molecular level changes. Environ. Sci. Pollut. Res. Int. 21, 12709-12022. doi: 10.1007/s11356-014-3210-3
Nair, R. (2016). "Effects of nanoparticles on plant growth and development," in Plant Nanotechnology, eds C. Kole, D. S. Kumar, and M. V. Khodakovskaya (Cham: Springer), 95-118.

Navarro, E., Piccapietra, F., Wagner, B., Marconi, F., Kaegi, R., Odzak, N., et al. (2008). Toxicity of silver nanoparticles to Chlamydomonas reinhardtii. Environ. Sci. Technol. 42, 8959-8964. doi: 10.1021/es801785m

Navratilova, J., Praetorius, A., Gondikas, A., Fabienke, W., von-der Kammer, F., and Hofmann, T. (2015). Detection of engineered copper nanoparticles in soil using single particle ICP-MS. Int. J. Environ. Res. Public Health 12, 15756-15768. doi: 10.3390/ijerph121215020

Nekrasova, G. F., Ushakova, O. S., Ermakov, A. E., and Uimin, M. A. (2011). Effects of copper (II) ions and copper oxide nanoparticles on Elodea densa Planch. Russ. J. Ecol. 42, 458-463. doi: 10.1134/S1067413611060117

Nhan, L. V., Ma, C., Rui, Y., Liu, S., Li, X., Xing, B., et al. (2015). Phytotoxic mechanism of nanoparticles: destruction of chloroplasts and vascular bundles and alteration of nutrient absorption. Sci. Rep. 5:11618. doi: 10.1038/srep11618

O’Brien, J. A., and Benková, E. (2013). Cytokinin cross-talking during biotic and abiotic stress responses. Front. Plant Sci. 4:451. doi: 10.3389/fpls.2013.00451

Okupnik, A., and Pflugmacher, S. (2016). Oxidative stress response of the aquatic macrophyte Hydrilla verticillata exposed to $\mathrm{TiO}_{2}$ nanoparticles. Environ. Toxicol. Chem. 35, 2859-2866. doi: 10.1002/etc.3469

Pakrashi, S., Jain, N., Dalai, S., Jayakumar, J., Chandrasekaran, P. T., Raichur, A. M., et al. (2014). In vivo genotoxicity assessment of titanium dioxide nanoparticles by Allium cepa root tip assay at high exposure concentrations. PLoS ONE 9:e87789. doi: 10.1371/journal.pone.0087789

Pallavi, Mehta, C. M., Srivastava, R., and Arora, S., Sharma, A.K. (2016). Impact assessment of silver nanoparticles on plant growth and soil bacterial diversity. Biotech 6:254. doi: 10.1007/s13205-016-0567-7

Patlolla, A. K., Berry, A., May, L., and Tchounwou, P. B. (2012). Genotoxicity of silver nanoparticles in Vicia faba: a pilot study on the environmental monitoring of nanoparticles. Int. J. Environ. Res. Public Health 9, 1649-1662. doi: 10.3390/ijerph9051649

Perreault, F., Samadani, M., and Dewez, D. (2014). Effect of soluble copper released from copper oxide nanoparticles solubilisation on growth and photosynthetic processes of Lemna gibba L. Nanotoxicology 8, 374-382. doi: $10.3109 / 17435390.2013 .789936$

Pokhrel, L. R., and Dubey, B. (2013). Evaluation of developmental responses of two crop plants exposed to silver and zinc oxide nanoparticles. Sci. Total Environ. 452-453, 321-332. doi: 10.1016/j.scitotenv.2013.02.059

Prasad, T. N. V. K.V., Sudhakar, P., Sreenivasulu, Y., Latha, P., Munaswamy, V., Raja Reddy, K., et al. (2012). Effect of nanoscale zinc oxide particles on the germination, growth and yield of peanut. J. Plant Nutr. 35, 906-927. doi: 10.1080/01904167.2012.663443

Qian, H., Peng, X., Han, X., Ren, J., Sun, L., and Fu, Z. (2013). Comparison of the toxicity of silver nanoparticles and silver ions on the growth of terrestrial plant model Arabidopsis thaliana. J. Environ. Sci. 25, 1947-1955. doi: 10.1016/S1001-0742(12)60301-5

Radad, K., Al-Shraim, M., Moldzio, R., and Rausch, W. D. (2012). Recent advances in benefits and hazards of engineered nanoparticles. Environ. Toxicol. Pharmacol. 34, 661-672. doi: 10.1016/j.etap.2012.07.011

Rafique, R., Arshad, M., Khokhar, M. F., Qazi, I. A., Hamza, A., and Virk, N. (2014). Growth response of wheat to titania nanoparticles application. NUST J. Engin. Sci. 7, 42-46. Available online at: http://journals.nust.edu.pk/index.php/njes/ article/view/133

Rai, M., Yadav, A., and Gade, A. (2009). Silver nanoparticles as a new generation of antimicrobials. Biotechnol. Adv. 27, 76-83. doi: 10.1016/j.biotechadv.2008.09.002

Raliya, R., Nair, R., Chavalmane, S., Wang, W. N., and Biswas, P. (2015). Mechanistic evaluation of translocation and physiological impact of titanium dioxide and zinc oxide nanoparticles on the tomato (Solanum lycopersicum L.) plant. Metallomics 7, 1584-1594. doi: 10.1039/C5MT00168D

Rastogi, A., and Pospíšil, P. (2010). Effect of exogenous hydrogen peroxide on biophoton emission from radish root cells. Plant Physiol. Biochem. 48, 117-123. doi: 10.1016/j.plaphy.2009.12.011

Rastogi, A., and Pospísil, P. (2012). Production of hydrogen peroxide and hydroxyl radical in potato tuber during the necrotrophic phase of hemibiotrophic pathogen Phytophthora infestans infection. J. Photochem. Photobiol. B Biol. 117, 202-206. doi: 10.1016/j.jphotobiol.2012.10.001 
Regier, N., Cosio, C., von-Moos, N., and Slaveykova, V. I. (2015). Effects of copper-oxide nanoparticles, dissolved copper and ultraviolet radiation on copper bioaccumulation, photosynthesis and oxidative stress in the aquatic macrophyte Elodea nuttallii. Chemosphere 128, 56-61. doi: $10.1016 /$ j.chemosphere.2014.12.078

Rico, C. M., Majumdar, S., Duarte-Gardea, M., Peralta-Videa, J. R., and GardeaTorresdey, J. L. (2011). Interaction of nanoparticles with edible plants and their possible implications in the food chain. J. Agric. Food Chem. 59, 3485-3498. doi: $10.1021 / \mathrm{jf104517j}$

Rico, C. M., Morales, M. I., Barrios, A. C., McCreary, R., Hong, J., Lee, W. Y., et al. (2013). Effect of cerium oxide nanoparticles on the quality of rice (Oryza sativa L.) grains. J. Agric. Food Chem. 61, 11278-11285. doi: 10.1021/jf404046v

Saha, N., and Dutta Gupta, S. (2017). Low-dose toxicity of biogenic silver nanoparticles fabricated by Swertia chirata on root tips and flower buds of Allium cepa. J. Hazard. Mater. 330, 18-28. doi: 10.1016/j.jhazmat.2017.01.021

Sanchez-Dominguez, M., Boutonnet, M., and Solans, C. (2009). A novel approach to metal and metal oxide nanoparticle synthesis: the oilin-water microemulsion reaction method. J. Nanopart. Res. 11, 1823. doi: 10.1007/s11051-009-9660-8

Santos, C. S. C., Gabriel, B., Blanchy, M., Menes, O., García, D., Blanco, M., et al. (2015). Industrial applications of nanoparticles - a prospective overview. Mater. Today Proc. 2, 456-465. doi: 10.1016/j.matpr.2015.04.056

Sharma, P., Jha, A. B., Dubey, R. S., and Pessarakli, M. (2012). Reactive oxygen species, oxidative damage, and antioxidative defense mechanism in plants under stressful conditions. J. Bot. 2012:217037. doi: 10.1155/2012/217037

Shaw, A. K., Ghosh, S., Kalaji, H. M., Bosa, K., Brestic, M., Zivcak, M., et al. (2014). Nano-CuO stress induced modulation of antioxidative defense and photosynthetic performance of syrian barley (Hordeum vulgare L.). Environ. Exp. Bot. 102, 37-47. doi: 10.1016/j.envexpbot.2014.02.016

Shi, J., Peng, C., Yang, Y., Yang, J., Zhang, H., Yuan, X., et al. (2014). Phytotoxicity and accumulation of copper oxide nanoparticles to the Cu-tolerant plant Elsholtzia splendens. Nanotoxicology 8, 179-188. doi: 10.3109/17435390.2013.766768

Slomberg, D. L., and Schoenfisch, M. H. (2012). Silica nanoparticle phytotoxicity to Arabidopsis thaliana. Environ. Sci. Technol. 46, 10247-10254. doi: 10.1021/es300949f

Soares, C., Branco-Neves, S., de-Sousa, A., Pereira, R., and Fidalgo, F. (2016). Ecotoxicological relevance of nano- $\mathrm{NiO}$ and acetaminophen to Hordeum vulgare L.: combining standardized procedures and physiological endpoints. Chemosphere 165, 442-452. doi: 10.1016/j.chemosphere.2016.09.053

Song, G., Hou, W., Gao, Y., Wang, Y., Lin, L., Zhang, Z., et al. (2016). Effects of $\mathrm{CuO}$ nanoparticles on Lemna minor. Bot. Stud. 57:3. doi: 10.1186/s40529-016-0118-x

Stampoulis, D., Sinha, S. K., and White, J. C. (2009). Assay-dependent phytotoxicity of nanoparticles to plants. Environ. Sci. Technol. 43, 9473-9479. doi: 10.1021/es901695c

Tangaa, S. R., Selck, H., Winther-Nielsen, N., and Khan, F. R. (2016). Trophic transfer of metal-based nanoparticles in aquatic environments: a review and recommendations for future research focus. Environ. Sci. Nano. 3, 966-981. doi: 10.1039/C5EN00280J

Teske, S. S., and Detweiler, C. S. (2015). The biomechanisms of metal and metaloxide nanoparticles' interactions with cells. Int. J. Environ. Res. Public Health 12, 1112-1134. doi: 10.3390/ijerph120201112

Torney, F., Trewyn, B. G., Lin, V. S., and Wang, K. (2007). Mesoporous silica nanoparticles deliver DNA and chemicals into plants. Nat. Nanotechnol. 2, 295-300. doi: 10.1038/nnano.2007.108

Tripathi, D. K., Singh, S., Singh, S., Srivastava, P. K., Singh, V. P., Singh, S., et al. (2017). Nitric oxide alleviates silver nanoparticles (AgNps)-induced phytotoxicity in Pisum sativum seedlings. Plant Physiol. Biochem. 110, 167-177. doi: 10.1016/j.plaphy.2016.06.015

Tripathi, D. K., Singh, V. P., Prasad, S. M., Chauhan, D. K., and Dubey, N. K. (2015). Silicon nanoparticles ( $\mathrm{SiNp}$ ) alleviate chromium (VI) phytotoxicity in Pisum sativum (L.) seedlings. Plant Physiol. Biochem. 96, 189-198. doi: 10.1016/j.plaphy.2015.07.026

Tubana, B. S., Babu, T., and Datnoff, L. E. (2016). A review of silicon in soils and plants and its role in US agriculture: history and future perspectives. Soil Sci. 181, 393-411. doi: 10.1097/SS.0000000000 000179

Unrine, J. M., Shoults-Wilson, W. A., Zhurbich, O., Bertsch, P. M., and Tsyusko, O. V. (2012). Trophic transfer of Au nanoparticles from soil along a simulated terrestrial food chain. Environ. Sci. Technol. 46, 9753-9760. doi: 10.1021/es3025325

Van, N. L., Ma, C., Shang, J., Rui, Y., Liu, S., and Xing, B. (2016) Effects of $\mathrm{CuO}$ nanoparticles on insecticidal activity and phytotoxicity in conventional and transgenic cotton. Chemosphere 144, 661-670. doi: 10.1016/j.chemosphere.2015.09.028

Van Breusegem, F., and Dat, J. F. (2006). Reactive oxygen species in plant cell death. Plant Physiol. 141, 384-390. doi: 10.1104/pp.106.078295

Vecerova, K., Večeřa, Z., Dočekal, B., Oravec, M., Pompeiano, A., Tř́íska, J., et al. (2016). Changes of primary and secondary metabolites in barley plants exposed to CdO nanoparticles. Environ. Pollut. 218, 207-218. doi: 10.1016/j.envpol.2016.05.013

Vinković, T., Novák, O., Strnad, M., Goessler, W., Jurašin, D. D., Paradiković, N., et al. (2017). Cytokinin response in pepper plants (Capsicum annuum L.) exposed to silver nanoparticles. Environ. Res. 156, 10-18. doi: 10.1016/j.envres.2017.03.015

Wang, P., Lombi, E., Zhao, F. J., and Kopittke, P. M. (2016). Nanotechnology: a new opportunity in plant sciences. Trends Plant Sci. 21, 699-712. doi: 10.1016/j.tplants.2016.04.005

Wang, Z., Xu, L., Zhao, J., Wang, X., White, J. C., and Xing, B. (2016). $\mathrm{CuO}$ Nanoparticle interaction with Arabidopsis thaliana: toxicity, parentprogeny transfer, and gene expression. Environ. Sci. Technol. 50, 6008-6016. doi: 10.1021/acs.est.6b01017

Wijnhoven, S. W. P., Peijnenburg, W. J. G. M., Herberts, C. A., Hagens, W. I., Oomen, A. G., Heugens, E. H. W., et al. (2009). Nano-silver - a review of available data and knowledge gaps in human and environmental risk assessment. Nanotoxicology 3, 109-138. doi: 10.1080/17435390902725914

Wong, M. H., Misra, R. P., Giraldo, J. P., Kwak, S. Y., Son, Y., Landry, M. P., et al. (2016). Lipid Exchange Envelope Penetration (LEEP) of nanoparticles for plant engineering: a universal localization mechanism. Nano Lett. 16, 1161-1172. doi: 10.1021/acs.nanolett.5b04467

Yadav, S. K. (2010). Heavy metals toxicity in plants: an overview on the role of glutathione and phytochelatins in heavy metal stress tolerance of plants. S. Afr. J. Bot. 76, 167-179. doi: 10.1016/j.sajb.2009. 10.007

Yin, L., Colman, B. P., McGill, B. M., Wright, J. P., and Bernhardt, E. S. (2012) Effects of silver nanoparticle exposure on germination and early growth of eleven wetland plants. PLOS ONE 7:e47674. doi: 10.1371/journal.pone. 0047674

Zuverza-Mena, N., Armendariz, R., Peralta-Videa, J. R., and Gardea-Torresdey, J. L. (2016). Effects of silver nanoparticles on radish sprouts: root growth reduction and modifications in the nutritional value. Front. Plant Sci. 7:90. doi: 10.3389/fpls.2016.00090

Zuverza-Mena, N., Martínez-Fernández, D., Du, W., Hernandez-Viezcas, J. A., Bonilla-Bird, N., López-Moreno, M. L., et al. (2017). Exposure of engineered nanomaterials to plants: insights into the physiological and biochemical responses-a review. Plant Physiol. Biochem. 110, 236-264. doi: 10.1016/j.plaphy.2016.05.037

Conflict of Interest Statement: The authors declare that the research was conducted in the absence of any commercial or financial relationships that could be construed as a potential conflict of interest.

The reviewer, ASP, and handling Editor declared their shared affiliation.

Copyright (c) 2017 Rastogi, Zivcak, Sytar, Kalaji, He, Mbarki and Brestic. This is an open-access article distributed under the terms of the Creative Commons Attribution License (CC BY). The use, distribution or reproduction in other forums is permitted, provided the original author(s) or licensor are credited and that the original publication in this journal is cited, in accordance with accepted academic practice. No use, distribution or reproduction is permitted which does not comply with these terms. 